

\section{DISCLAIMER}

This report was prepared as an account of work sponsored by an agency of the United States Government. Neither the United States Government nor any agency Thereof, nor any of their employees, makes any warranty, express or implied, or assumes any legal liability or responsibility for the accuracy, completeness, or usefulness of any information, apparatus, product, or process disclosed, or represents that its use would not infringe privately owned rights. Reference herein to any specific commercial product, process, or service by trade name, trademark, manufacturer, or otherwise does not necessarily constitute or imply its endorsement, recommendation, or favoring by the United States Government or any agency thereof. The views and opinions of authors expressed herein do not necessarily state or reflect those of the United States Government or any agency thereof. 


\section{DISCLAIMER}

Portions of this document may be illegible in electronic image products. Images are produced from the best available original document. 


\section{DISCLAIMER}

This report was prepared as an account of work sponsored by an agency of the United States Government Netther the Unıted States Government nor any agency thereof nor any of their employees, makes any warranty, express or umplied or assumes any legal liability or responsibility for the accuracy. completeness or usefulness of any information, apparatus, product, or process disclosed, or represents that its use would not infringe privately owned rights Reference herein to any specific commercial product, process, or service by trade name, trademark, manufacturer, or otherwise does not necessarily constitute or imply its endorsement, recommendation or favor ing by the United States Government or any agency thereof The views and opinions of authors expressed herein do not necessarly state or reflect those of the Unted States Government or any agency thereof

Printed in the United States of America Avallable from National Technical Information Service

US Department of Commerce

5285 Port Royal Road

Springfield, VA 22161

NTIS price codes

Paper copy:

A04

Microfiche copy: A01

$$
\begin{aligned}
& \text { DO NOT MICROFILM } \\
& \text { COVER }
\end{aligned}
$$




\section{VERIFICATION OF GEOLOGICAL/ENGINEERING MODEL IN WATERFLOOD AREAS}

Topical Report

By NIPER--286

B. Sharma M. Szpakiewicz M. Honarpour R.A. Schatzinger R. Tillman DE89 000710 December 1988

Work Performed Under Cooperative Agreement No. FC22-83FE60149

Prepared for

U.S. Department of Energy

Assistant Secretary for Fossil Energy

James W. Chism, Project Manager

Bartlesville Project Office

P.O. Box 1398

Bartlesville, OK $\mathbf{7 4 0 0 5}$

Prepared by

IIT Research Institute

NATIONAL INSTITUTE FOR PETROLEUM AND ENERGY RESEARCH

P.O. Box 2128

Bartlesville, OK 74005

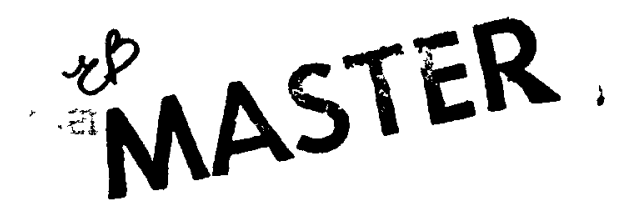


Abstract.......................................................1

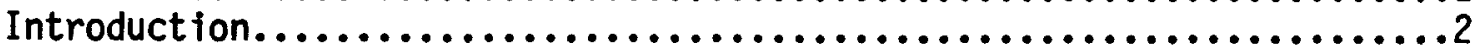

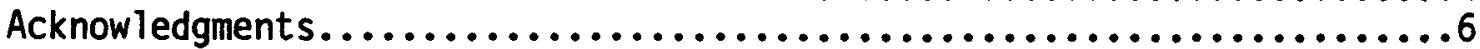

Geology......................................................6

Introduction..............................................6

Depositional model of Muddy formation.........................

Architecture and geological properties of barrier island and

valley fill deposits in Bell Creek.............................8

Reservoir Quality of the Barrier Island Complex.................24

Reservoir definition........................................24

Geological model of barrier island deposit.........................23

Reservoir framework.........................................26

Petrographic evidence.....................................30

Distribution of reservoir properties in the barrier is land deposit...38 Distribution of reservoir properties from log interpretations......39

Heterogeneity index map....................................41

Distribution of clays........................................43

Production performance analysis $. . \ldots \ldots \ldots, \ldots, \ldots, \ldots, \ldots, \ldots, \ldots, \ldots, 44$

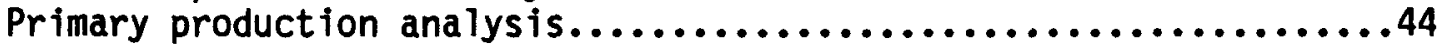

Secondary production analysis...................................50

Secondary waterfront movement analysis.........................50

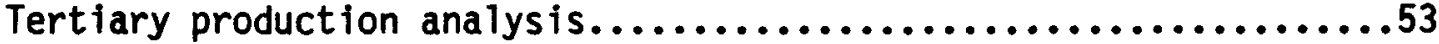

Pressure transient testing analysis.........................53

Verification of geological and engineering model of reservoir.......53

Conclusions...................................................58

References...............................................60

\section{TABLES}

1. Quantitative XRD determination of mineralogy for subsurface samples from Bell Creek field and a nearby outcrop..............16

2. Cross section $\mathrm{H}^{-\mathrm{H}^{\prime}}$ formation thickness comparison based on interpretation of gamma ray, SP, resistivity logs, and available cores.......................................20

3. Petrophysical properties of barrier island and non-barrier

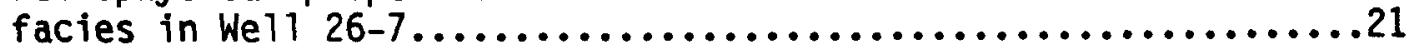

4. Summary of documented reservoir heterogeneities in Be11 Creek, Unit A cores; major elements of improved geological/engineering model and their preliminary scaling......25

5. Classification of productive and non-productive facies (documented in cores) of muddy sediments in Bell Creek reservoir..........................................27

6. Documented prevailing stacking patterns of Muddy sediments in central part of Unit A, Bell Creek field...........27 


\section{ILLUSTRATIONS}

Page

1. Index map shows units comprising Bell Creek field and well control...........................................4

2. Location map for cross sections with in Unit A of Bell Creek field..........................................

3. Relationship of deposition and errosion to sea-level changes during lower Cretaceous stages in NE Powder River Basin based on lithostratigraphy of Muddy formation deposits in Be11 Creek..............................................9

4. Typical depositional sequence of barrier island facies and variations in their depositional energy and geologic characteristics.......................................10

5. Conceptual distribution of observed barrier and related non-barrier facies in Bell Creek field.......................12

6. Gamma ray log responses across hydraulic barrier dividing production units "A" and "B" in Bell Creek field................14

7. Correlation of core-derived geologic profile with log

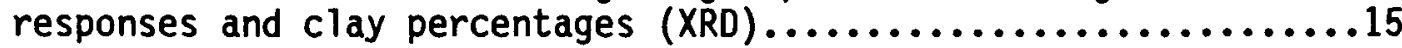

8. Log and core based diagramatic lithogenetic cross-section A-A' interpreting relationship of major genetic units of Muddy formation in TIP area, Bell Creek field........................................18

9. Structural cross sections (B-B') and (C-C') of Muddy formation sandstones in Unit $A, B e 11$ Creek field...............23

10. Structural contours (in feet below M.S.L.) on the top of the Muddy sandstone................................29

11. Isopach map of the Muddy sandstone in the study area...........30

12. Cross-sections $\left(D-D^{\prime}\right)$ and $\left(E-E^{\prime}\right) \ldots \ldots \ldots \ldots \ldots \ldots \ldots \ldots \ldots \ldots$

13. Petrographic summary for figure $8, \ldots \ldots \ldots \ldots \ldots \ldots \ldots \ldots \ldots . . \ldots \ldots$

14. Distribution of Dykstra-Parsons coefficients obtained from air-permeability data in the study area..................35

15. Log-derived clay content index of the barrier island sandstone in the study area...............................36

16. Log derived heterogeneity index (LHI) of the barrier island sandstones in the study area... 


\section{ILLUSTRATIONS - Continued}

17. Distribution of geometric means of the air permeability data for wells in the study area.........................40

18. Average log-derived porosities (in percentage) of the barrier island sandstones in the study area...............42

19. Distribution of primary reserves in thousands of barrels in the study area based on production decline analysis.....................................46

20. Distribution of cumulative primary production in thousands of barrels, up to September 1970 in central part of Unit A, Bell Creek field..................47

21. Monthly peak primary oil production rate in thousands of barrels/month in the central part of Unit A, Bell Creek field...............................48

22. Pressure pulse and falloff test results prior to initiation of chemical flooding.

23. Cumulative waterflood production in thousands of barrels through September 1986 in central part of Unit A, Bell Creek field...............................51

24. Twenty percent water advancement map through January 1981

25. Tertiary cumulative production in thousands of barrels in the TIP area as of May 1986.

26. Summary of primary reserves and primary, waterflood, and tertiary production results in the study area of Unit $A$ in Bell Creek field. 


\title{
VERIFICATION OF GEOLOGICAL/ENGINEERING MODEL IN WATERFLOOD AREAS
}

By B. Sharma, M. Szpakiewicz, M. Honarpour, R. Schatzinger, and R. Tillman

\begin{abstract}
A geological/engineering model was constructed for the extended Tertiary Incentive Project (TIP) mile area of Unit A in Bell Creek field, Powder River County, Montana. The model was constructed to develop a methodology for characterizing reservoir heterogeneity for barrier island deposits. This report summarizes the status of the NIPER geological/engineering model as of September 1987.

A structure map of Muddy formation sandstones and an isopach map of the reservoir were constructed to delineate the framework of the pay zones. In addition, reservoir quality was differentiated by grouping facies into three classes. Valley incisions and indications of localized faulting have been documented within the barrier-island deposit. Valley fill deposits unconformably overlie portions of the barrier island sequence in the Bell Creek field.
\end{abstract}

The distribution of geological heterogeneities and their influence on fluid flow characteristics were determined by generating maps and cross sections based on integration of log, core, petrographic data, and the qualitative information gathered from analogous outcrops. Parameters mapped include the distribution of porosity, log-derived geometric mean permeability, clay content, and Dykstra-Parsons coefficients of permeability variations. The salient features of the geological and fluid flow model of the barrierisland deposit include:

1. The axial part of the deposit has the best reservoir quality because of lithostratigraphic patterns and pores which are relatively free from clays and other cements. Elongated zones parallel to the depositional strike of the Muddy formation are heterogeneous because of the stacking of facies and increased cementation or selective compaction, or both.

2. The effects of faulting (and probably fracturing), valley incisions, 
diagenesis, and compaction have introduced overlapping (multigenetic) heterogeneities effecting fluid flow characteristics.

3. A wide variety of scale of heterogeneities (structural, depositional facies, diagenetic) occurs within the field.

4. Production from several stacked shallowing-up barrier-island sandstones is strongly effected by post-barrier erosion and valley fill sedimentation.

5. Because the low-permeability back-barrier facies and their interfingering with lagoonal facies acted as a barrier to the oil bank swept during waterflood operations, the area of best waterflood performance lies between the barrier axis and the back-barrier deposits.

The geological and engineering models were integrated and account for areal variations in production data. The correlation of production performance with geological heterogeneities strongly supports the geological model of the barrier island deposit.

Results of the mathematical simulation of the geological/engineering model will be reported later.

This report covers the work performed from May 1, 1987 to August 31, 1987 in fulf 11 lment of task $10 \mathrm{~A}$ for project $B E 1$ being performed for the Department of Energy.

\section{INTRODUCTION}

Bell Creek field is located in Carter and Powder River counties of Montana, on the northeastern flank of the Powder River Basin (Fig. 1). This field was selected for a study seeking to develop a methodology for construction of a quantitative geological/engineering model capable of predicting the effect of reservoir heterogeneities on flow patterns and on residual oil saturation within barrier island sandstone reservoirs. Bell Creek field was selected because (1) its production is mainly from a prolific barrier island deposystem, (2) analogous outcrops of the formation occur within 40 miles of the field, and (3) primary, secondary, and tertiary subsurface data are available from the field. ${ }^{1}, 11$

The distribution, continuity, and internal characteristics of marine 
sandstones are controlled by the environment to deposition and tectonic setting as well as by subsequent erosional, tectonic, and diagenetic processes. An understanding of the depositional history of the reservoir is important for predicting the genesis, distribution, magnitude, and frequency of occurrence of the various heterogeneities. Based on a spatial description of the fluid flow properties in the reservoir and analys is of performance and pressure distribution during different recovery stages, the most important geological heterogeneities that control fluid production have been identified, and a preliminary scaling has been completed.

The construction of a detailed geological/engineering model is the basis for development of the methodology for characterizing reservoir heterogeneity. The NIPER geological/engineering model is the subject of this report. The area selected for geological and production performance studies is a four-section area within production Unit A (Figs. 1 and 2) which includes the Tertiary Incentive Project (TIP) pilot. Log, well test, production, and core data were acquired for construction of the geological model of a barrier island reservoir. In this investigation, emphas is was on the synthesis and quantification of the abundant geological information acquired from the literature and field studies (subsurface and outcrop) by mapping the geological heterogeneities that influence fluid flow. The geological model was verified by comparing it with the exceptionally complete production data available for Bell creek field. This integration of new and existing information from various geological, geophysical, and engineering disciplines has enabled better definition of the heterogeneities that influence production during different recovery operations.

The succession of lithology, sedimentary structures, and textures in the barrier island Muddy sandstone at Be11 Creek field is similar to those observed in recent barrier island deposits. ${ }^{2}$ Characterization of Bell Creek field may shed light on heterogeneities encountered in other reservoirs producing from similar barrier bar deposits. 


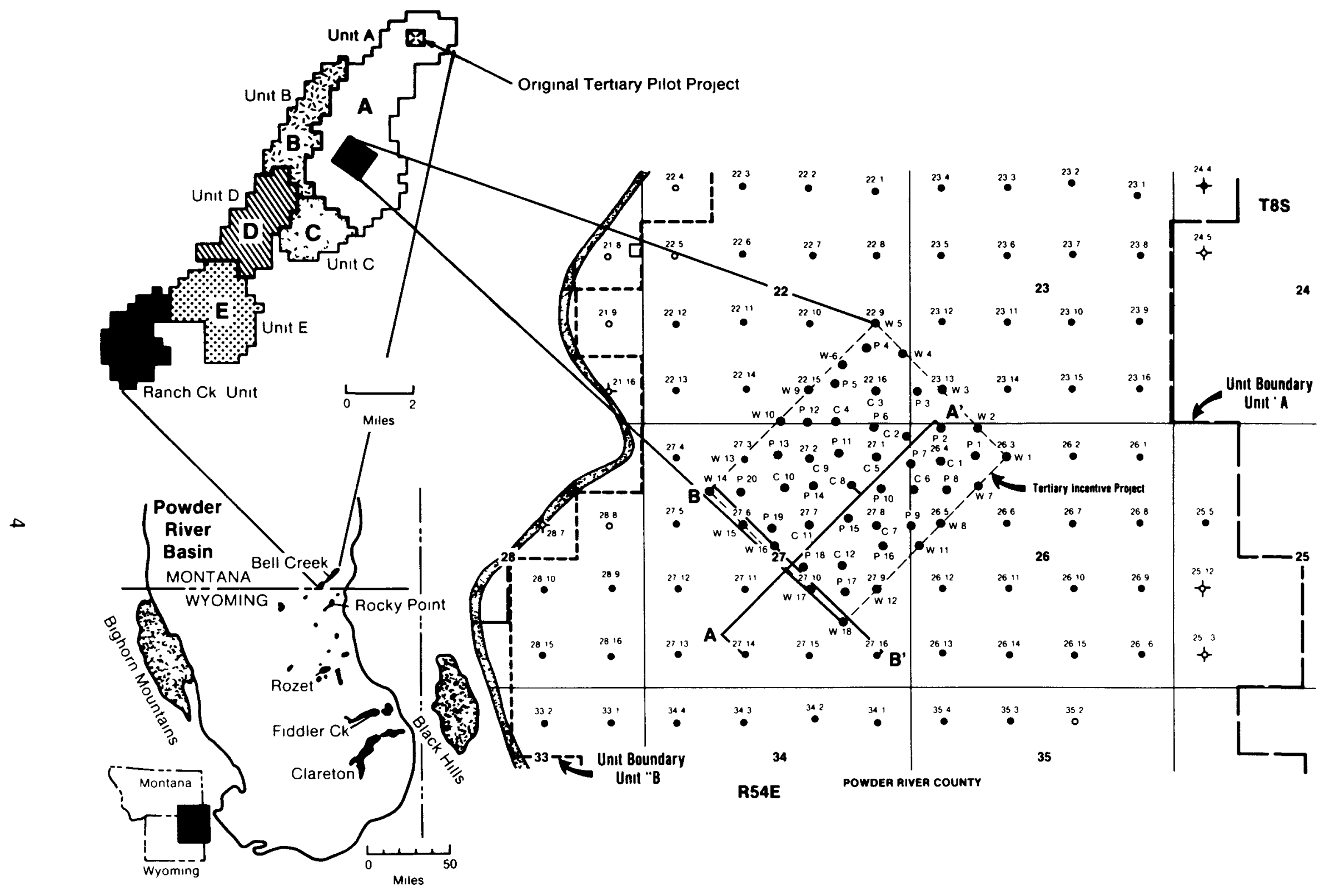

FIGURE 1. - Index map shows units comprising Bell Creek field and well control. P, production wells; $W$, water injection wells; and $C$, chemical injection wells. 


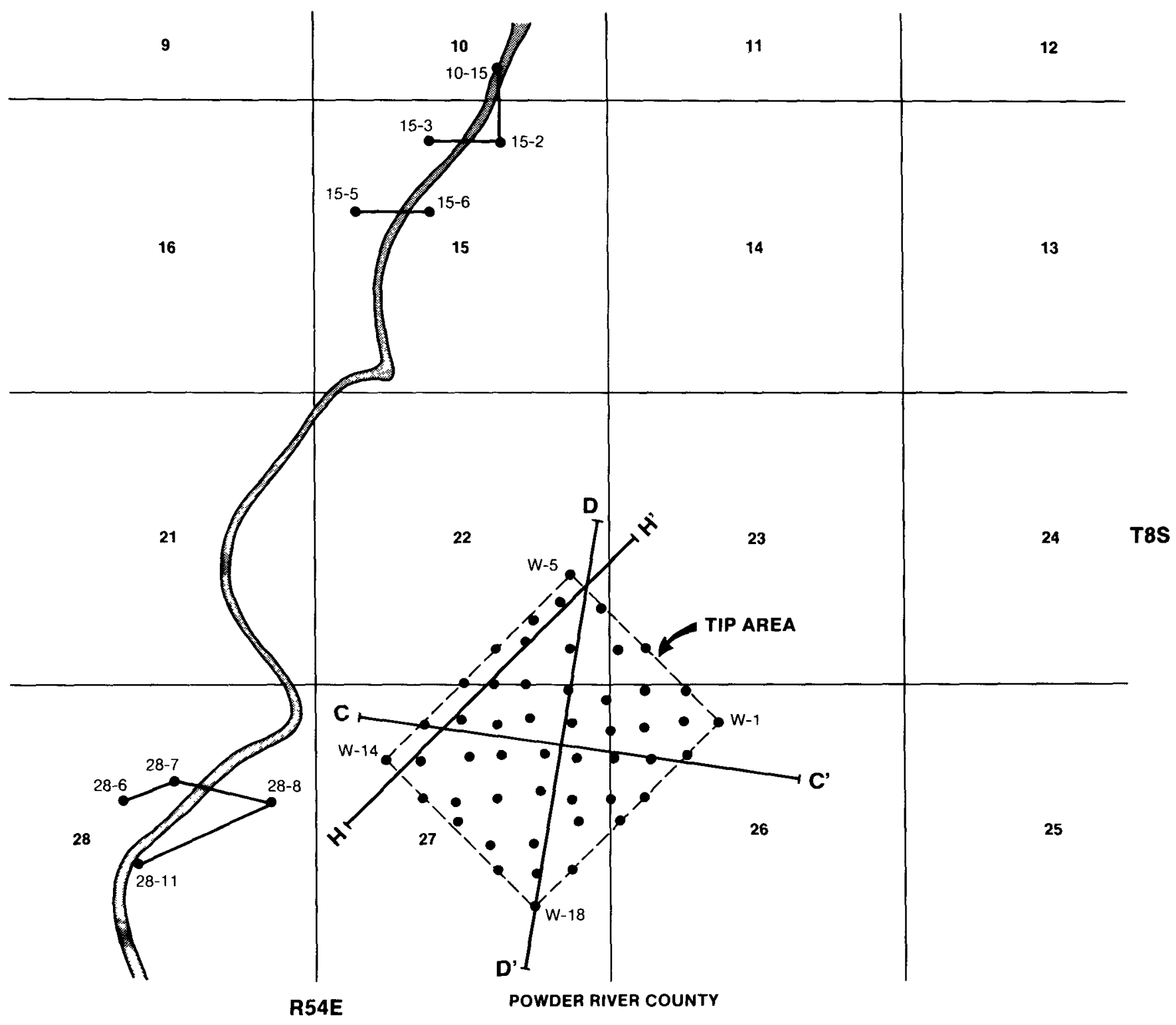

FIGURE 2. - Location map for cross sections within Unit A of Bell creek field. 


\section{ACKNOWLEDGMENTS}

Special thanks are due to Gary-Williams 0 il Producers Inc. for providing laboratory and field data, cores, and logs to carry out this research. The authors also wish to thank NIPER employees Susan Jackson who contributed to the geological investigations and gathering of field data and Liviu Tomutsa and Guy deVerges who assisted in processing the data and preparing the graphs.

\section{GEOLOGY}

\section{Introduction}

The Lower Cretaceous Muddy formation, which produces oil from Unit A in Bell Creek field, Montana, is composed of two genetically different major sandstone reservoir units interpreted as (1) barrier islands (littoral marine bars) and (2) valley fills.

The entire barrier island assemblage and related environments of deposition are underlain and overlain by marine shales -- Sku1l Creek and She 11 Creek/Mowry shale, respectively.

$0 i 1$ productivity in Bell Creek production Unit $A$ depends on at least five geological factors: ${ }^{3-5}$

(1) stratigraphic relation of the barrier sandstones to the valley fill deposits;

(2) development and architecture of the barrier island facies

- internal distribution of facies within the dominant sedimentary cycle of the barrier deposit, and

- stacking or overlap of subsequent fragmental

cycles of barrier deposition;

(3) depth and width of erosional cuts into the top of barrier island and type of their infilling;

(4) distribution, type, and degree of importance of diagenesis (clay filling, compaction); and

(5) local faulting which appears to modify fluid flow patterns between individual wells and groups of wells. 


\section{Depositional Model of Muddy Formation}

Paleogeographic reconstructions during Muddy deposition in the area of Bell Creek field clearly show the interrelationship between dominant depositional environments including continental (delta channels and deltaic plain); brackish marine (lagoon, estuary, and tidal flat); and coastal marine (barrier islands) sedimentation in the northeastern Powder River Basin where Bell Creek oil field is located.

Since the discovery of Bell Creek field, at least three different concepts regarding relationships between barrier-bar sandstones and valley fill deposits in the northeastern part of the Powder River Basin have been presented:

1. The barrier deposits lie stratigraphically above an unconformity which separates them from the underlying Sku11 Creek shale. ${ }^{6}, 7$

2. Valleys (and their subsequent fills) are incised into barrier island deposits and are stratigraphically younger. The barrier island deposits are genetically related to the Skull Creek shale. ${ }^{8}$

3. The barrier islands and valley fills are in part synchronous. ${ }^{5}$

There are no indications that valley fills underlie the barrier sandstones in the Bell Creek Unit A area. In all of the recently described cores from Unit $A$, the lower shoreface barrier facies conformably overlie the marine Sku11 Creek shales." The same is true for analogous barrier island sandstone outcrops exposed near New Haven, Wyoming, about 40 miles southeast of Bell creek field. Incision of valley fills into the top of barrier deposits is, however, commonly observed in Bell Creek cores, strongly supporting Weimer's concept $^{8}$ (number 2 above).

However, if the Bell Creek barrier was deposited on a tectonically uplifted high, ${ }^{9}$ it would be possible to accept at least two independent periods of valley erosion and fill during deposition of the barrier and associated deposits. The first period of erosion and subsequent valley fill may have occurred during lower Muddy sedimentation in topographic lows (as documented in the Recluse field area) ${ }^{6}$ and a later one postdated the upper Muddy sedimentation which incised into the barrier island sandstones and lagoonal facies in the Bell Creek area. The Bell Creek Muddy oil reservoir, therefore, appears as a complicated system of barrier sandstones with channel 
cuts and subsequent vall ley fills unconformably superimposed. This wodel finds mumerous recent analogues allong the Texas Culf Coast and elsewhere. Recent patterns of the barrier island sedimentation in the United States indicate that -valley fill sediments either underlying or incised into the barrier island top (as is the case im Bell Creek) ocour commomily together and should be considered as typicall association of this type of mear-shore sandstone deposit.

A question concerms imfluence of eustacy on sandstome occurremce, erosionall cuts, and infitiing of valley incisions witth mon-marime sedinemts. Figure 3 shows the correllation and the stratigraphic sequence of the lover Cretaceous (Albian) periods of deposition and erosion with sea level high- and How stands. Skull Creek shales and barriter island sandstones were deposited during $\pi_{4}$ and $T_{5}$ time intervalls, respectively. Whem sea level dropped during T. the vallieys incised into the barrier tops. Accumullation of valley fillis took place during subsequent sea level rise, marked $\pi_{\pi}$ on the diagran. Deposition of the Muddy fonmation, with an average total thickmess of about 40 feet as interpreted from llogs, was completed during $\pi_{\pi}$. Further continuous deepening of sea (transgression period) in the Bell1 Creek area resulted in enwelloping the Muddy conplex in Albian Shell Creek/mowry shale and Cemomanian (Upper Cretaceous) Belle Fourche shalle. The stacking of barrier island facies belonging to different episodes of barrier formation (progradatiom/regressiom) resulting from minor fluctuations of sea levell during the $T_{5}$ period is discussed further in this report.

Architecture and Lithogenetic Oraracteristics of Barrier Island and Valley Fill Deposits in Bell Creek

Aypical stratigraphic cyclle of major barrier is land facies exhibits predictable characteristics (Fig. 4). Deposition-rellated reservoir qualitty and productivity potentiall of barrier-istland sedinents should coincide with: (1) patterms of verticall stacking of facies,

(2) changes in thickmess of barrier island deposits due to erosion, and (3) the range of permeabilitity wallues in productive facies. Stacking of severall cycles of barrier sedirmentation is recogmized in Bell Creek cores; for example, in well w-116 where 21 feet of shoreface and foreshore facies is under laim by 2.8 feet of possible backlbarrier (washower) ffacies and overnain by another 3.6 feet of 


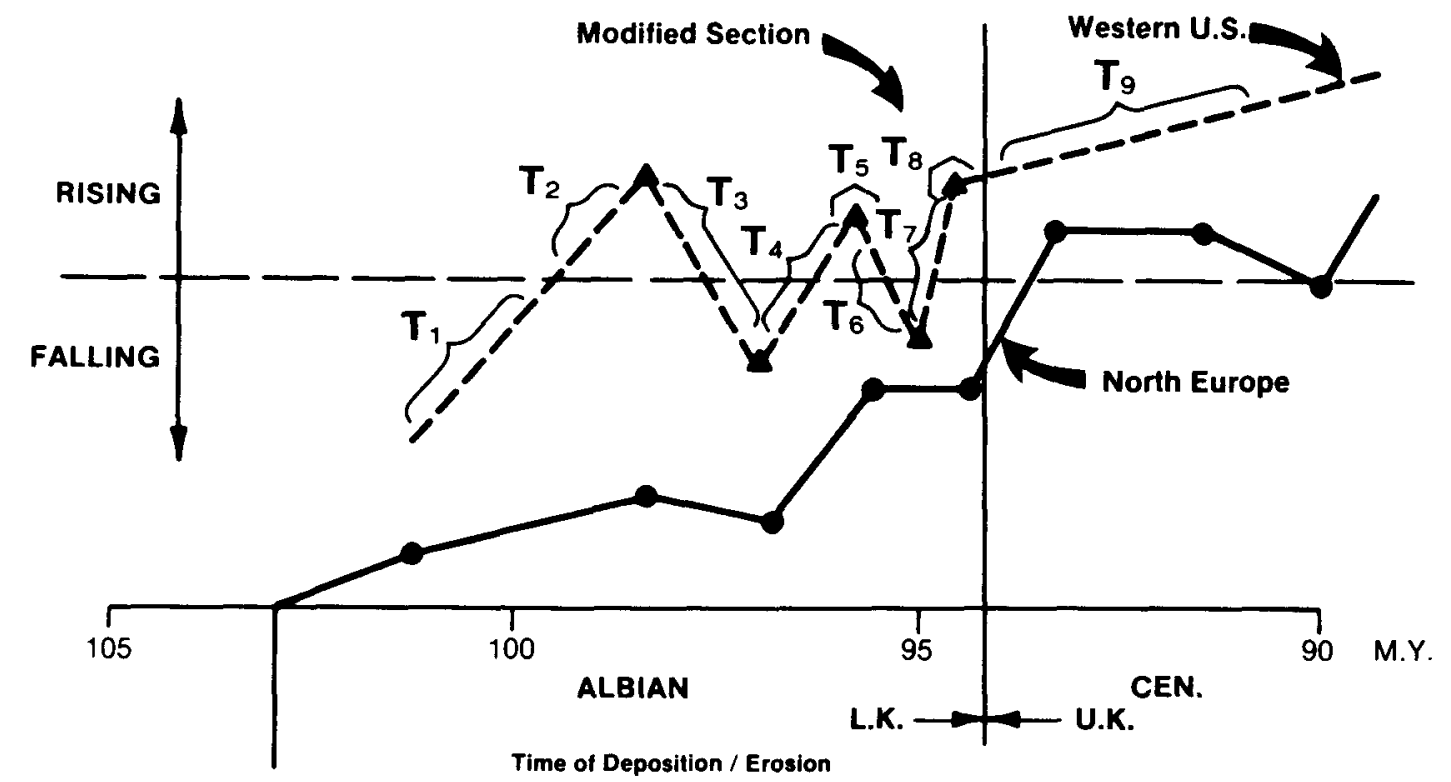

$T_{1}$ - Inyan Kara Group (Lakota and Fall River Sandstones)

$\mathbf{T}_{2}$ - Skull Creek Shale

$\mathbf{T}_{3}$ - Lower Muddy Valley incisions (In topographic lows)

T. - Lower Muddy Valley filling (accumulation in topographic lows) (Newcastle Type)

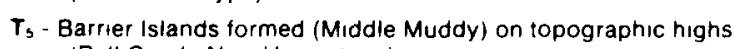

$\mathbf{T}_{6}$ - Valley incisions into Barrier Islands (Bell Creek, New Haven area)

$T_{1}$ - Valley infill (Upper Muddy) brackish marine and continental (Bell Creek)

$\mathbf{T}_{\mathrm{s}}$ - Shell Creek / Mowry Shale

$T_{9}$ - Belle Fourche Shale (Bell Creek. New Haven tvoe)

FIGURE 3. - Relationship of deposition and errosion to sea-level changes during lower Cretaceous stages in NE Powder River Bas in based on lithostratigraphy of Muddy formation deposits in Bell Creek. 


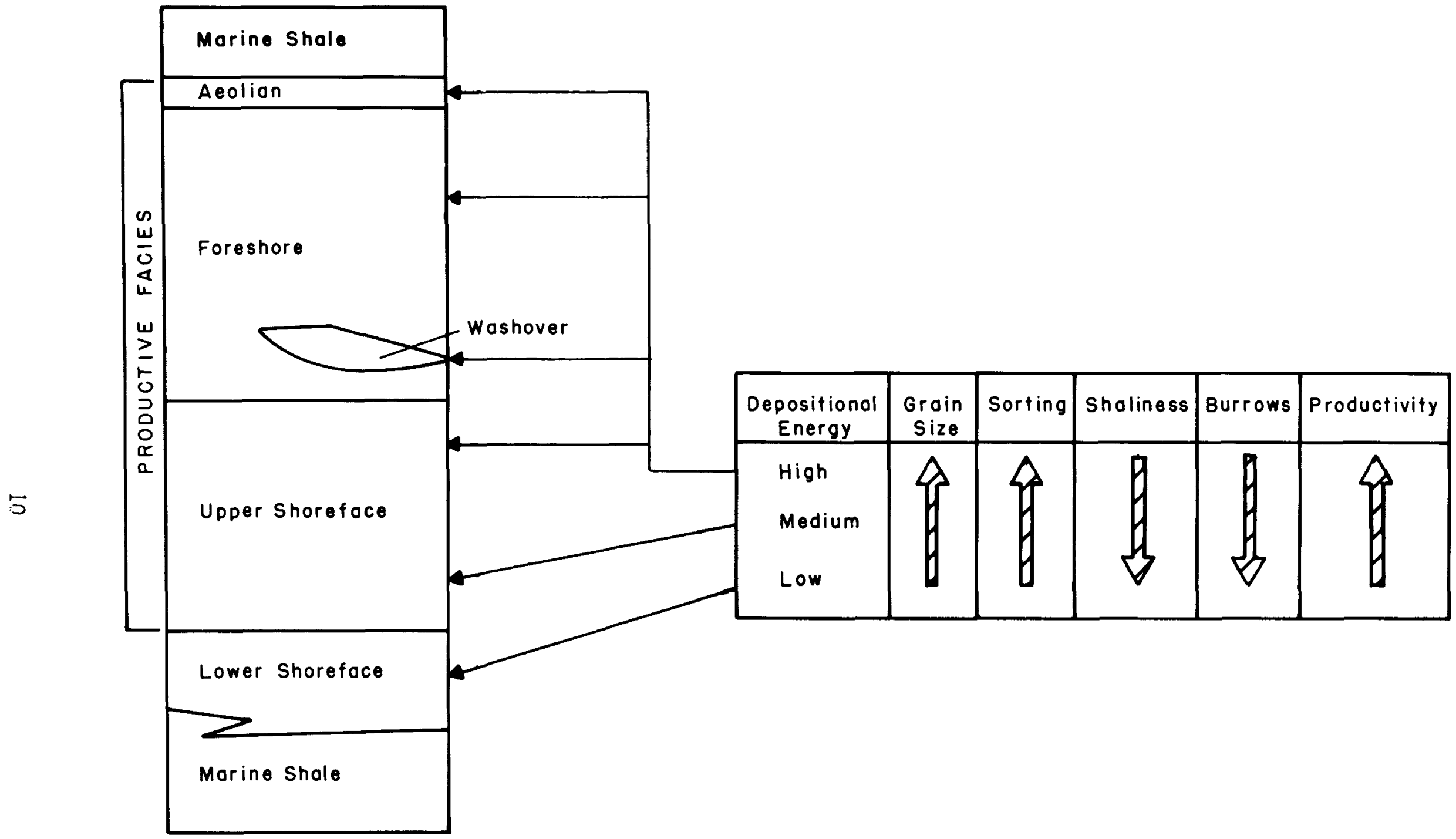

FIGURE 4. - Typical depositional sequence of barrier island facies and variations in their depositional energy and geologic characteristics. 
possible backbarrier (washover) facies. The thickness of barrier island sandstones representing one or more overlapping sedimentary cycles varies, with a maximum observed development of 32 feet.

The pattern of shifting of the barrier bodies in time and space has not yet been documented. In addition to local thickening due to deposition of more than one cycle of barrier sedimentation, total barrier thicknesses are seldom preserved because of erosional processes during and after deposition of the barriers. Most susceptible to erosion are the aeolian deposits which commonly occur at the top of the barrier (Fig. 5); deolian deposits are only rarely preserved in ancient shoreline deposits. However, thin layers of dune deposits overlying foreshore facies were observed in some Bell Creek cores; for example, in well C-8. Foreshore and shoreface (supratidal, intertidal, and subtidal) facies have much better preservation potentia1, and they compose most of the producing barrier island sandstone interval. Stacking of foreshore and shoreface sequences results from relative sea level drop (regression) and sea level rise (transgression). During periods of regression, the original barrier island sequence was partially eroded, and during the following transgression another barrier island sequence was deposited above remnants of the previous one. In a series of events subsequent to and independent of barrier building, valley cuts locally removed significant portions of the upper part of the barrier complex. Locally, only remnants of the original barriers are preserved, and in extreme cases the entire barrier was removed by the erosional processes which cut near or below the base of the barrier (Fig. 5). Significant erosional reduction of thickness of barrier island sediments (including local complete removal) strongly affects their storage capacity and transmissivity to fluids. Complete hydraulic disconnection of the reservoir may occur, as seems to be the case between production Units A and B (Fig. 1).

There are indications of two stages of valley incision during late Muddy deposition; an earlier stage affecting in most cases only barrier island deposits, and a later stage, affecting barrier island and the valley fill deposits of the first stage, as documented at the western extremity of Unit $A$. 


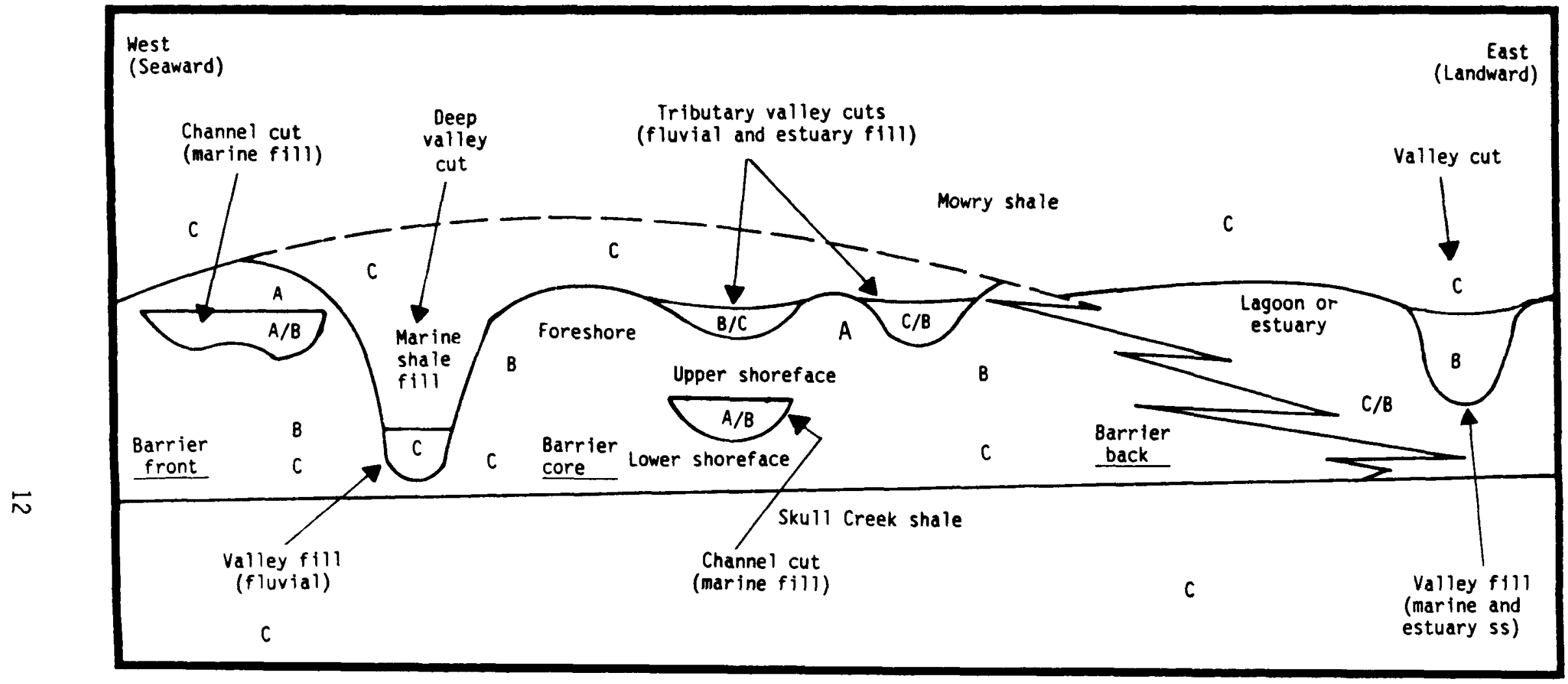

Classification of deposits $(A, B, C)$ as in table 5 . Eroded top of the barrier.

Note details of valley cut infillings.

FIGURE 5. - Conceptual distribution of observed barrier and related nonbarrier facies in Bell Creek field. Quality of reservoir rocks indicated as $A, B$, and $C$ is described in table 5 . 
A ribbon-like incision filled with very low energy shaley/silty sediments of the second stage of erosion cuts down about 35 feet into the Muddy deposits (almost to the base) and creates a steep and narrow (about 500 feet wide) barrier to hydraulic conductivity between production Units $A$ and $B$. This barrier has been documented in several logs from wells within the barrier (dry holes) (Figs. 6 and 7). Different pressure regimes and different positions of water-oil contacts on both sides of the barrier reflect effective isolation of the two production units. The thickness of the divided barrier island deposits tends to increase westward within Unit A suggesting the position of the barrier-front is west of Unit $A$. No significant faulting between these two production units is indicated. The origin of this deep cut and its infilling is not quite clear because cores are not available for geological examination. The gamma ray log signature above 4-foot-thick remnants of eroded barrier island suggests probable marine, shaley fill acting as a hydraulic barrier, which was deposited in a deep cut eroded by strong subsea currents.

Valley cuts into the barrier island and into synsedimentary lagoonal deposits within production Unit A, east of the major hydraulic barrier, were filled with argillaceous fluvial (continental) and marine deposits of much lower reservoir quality before and during the transgressive stage. Several types of valley fills are shown in figure 5.

Most of the valley fills described in Bell Creek cores from Unit A are of nonmarine origin, have very fine mean grain size (75 to 125 microns), and contain abundant clay matrix. X-ray diffraction analyses of barrier island and valley fill sandstone samples from the subsurface and from analogous outcrops revealed significant differentiation of clay assemblages (table 1). In barrier island sandstones, kaolinite and illite predominate and only traces of smectite are present, whereas smectite and kaolinite occur commonily in valley fill sandstones and siltstones. Clay types and percentages related to core-derived geologic profile and log responses of barrier island and valley fill facies identified in well W-7 are shown in figure 7.

Further petrographic, X-ray diffraction, and capillary pressure analyses of barrier island (Zone 2) and valley fill (Zone 1) deposits are underway to depict the most important geologic differences of the two types of sediments and to recognize and characterize their fundamental reservoir properties. 
Unit "8"

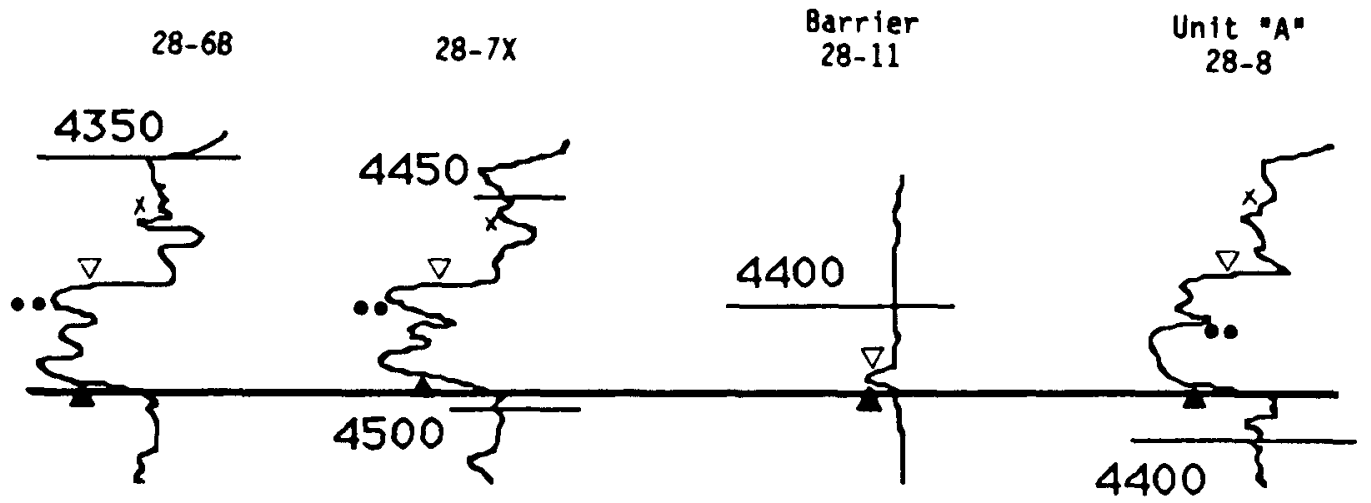
Unit "B"
Barrier
$10-15$
Unit " $A$ "
$15-3$
$15-2$

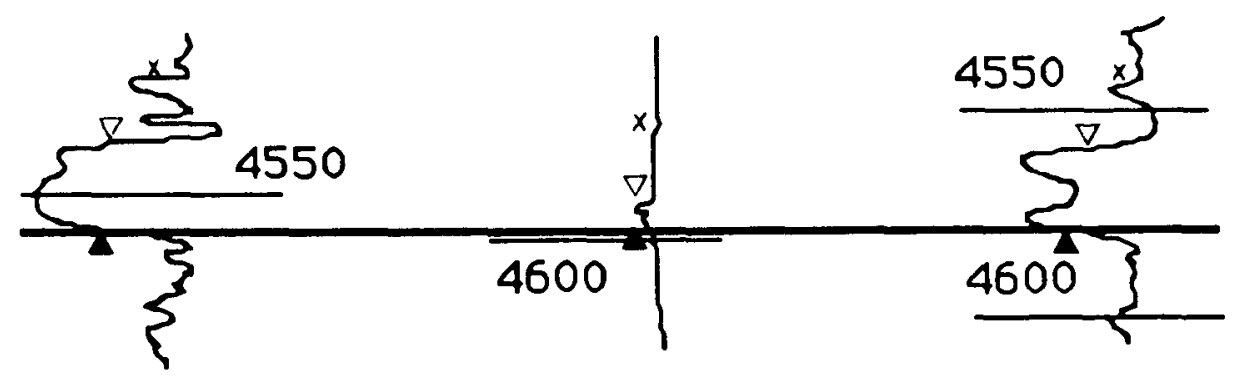

Explanation

a Base of Muddy formation (barrier island sandstones).

$\nabla$ Top of Muddy sandstones.

... Inferred top of barrier island sandstones.

$x$ Inferred top of Muddy formation

FIGURE 6. - Gama ray log responses across hydraulic barrier dividing production Units " $A$ " and " $B$ " in Bell Creek oil field. Logs indicate deep cuts into Muddy formation followed by filling by shale. Wells 28-11 and 10-15 are dry holes which are projected into the line of section. The SP logs from these two wells indicate a deep erosional cut into the Muddy formation barrier island sandstone. 
PERCENTAGE OF CLAYS IN WELL W-T

SP

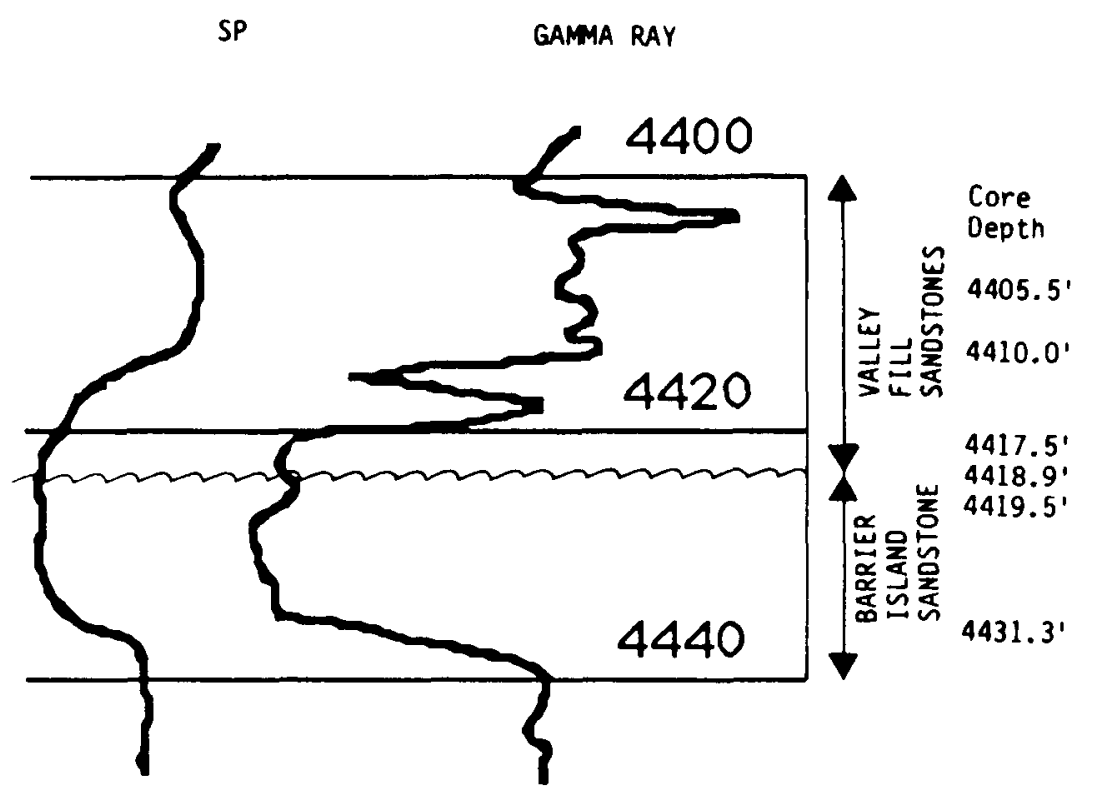

GAMMA RAY

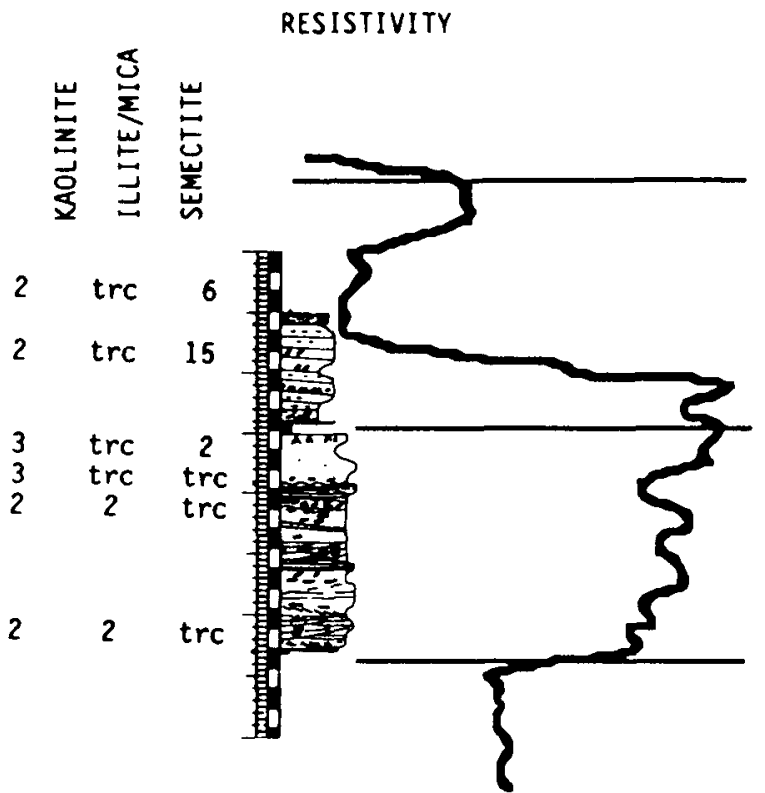

FIGURE 7. Correlation of core-derived geologic profile with log responses and clay percentages (XRD). Barrier island sandstones are overlaid by valley fill sandstones which have inferior production

characteristics. Unconformity between barrier island and valley fill is observed in core at 4,419.3 feet. Smectite (mixed layer clay) is significantly more abundant in valley fill deposits. Illite/mica ismore abundant in barrier island sandstone. 
TABLE 1. - Quantitative XRD determination of mineralogy for subsurface samples from Bell Creek field and a nearby outcrop.

$G M=$ Green Mountain outcrop.

Mineralogy in Percent

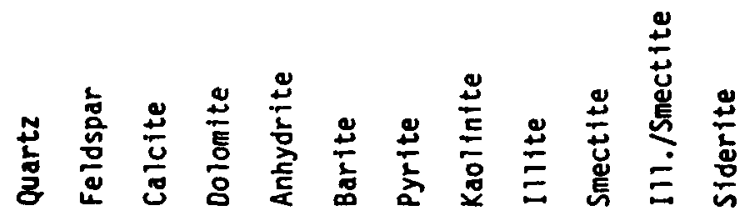

Wel1 Depth Depositional Setting

(ft)

Subsurface

\begin{tabular}{|c|c|c|c|c|c|c|c|c|c|c|c|c|c|}
\hline C-8 & 4351 & Lagoon & 76 & 3 & - & 4 & - & - & - & 7 & 8 & $\operatorname{tr}$ & - \\
\hline $27-16$ & 4303.3 & Washover & 88 & 2 & $\operatorname{tr}$ & $\operatorname{tr}$ & - & - & - & 6 & 4 & - & $\operatorname{tr}$ \\
\hline$W-14$ & 4309.3 & U./L/Shoref ace & 89 & 3 & $\operatorname{tr}$ & $\operatorname{tr}$ & - & - & $\operatorname{tr}$ & 5 & 3 & tr & - \\
\hline $\begin{array}{l}27-14 \\
27-14\end{array}$ & $\begin{array}{l}4329.5 \\
4331.5\end{array}$ & $\begin{array}{l}\text { U. Shoref ace/foreshore } \\
\text { U. Shoref ace/foreshore }\end{array}$ & \multirow{2}{*}{$\frac{E}{=}=\begin{array}{l}94 \\
90 \\
91 \\
88\end{array}$} & $2^{\operatorname{tr}}$ & tr & $\begin{array}{l}\operatorname{tr} \\
2\end{array}$ & $\overline{-}$ & - & $\overline{t r}$ & $\begin{array}{l}4 \\
4\end{array}$ & $\begin{array}{l}2 \\
2\end{array}$ & $\begin{array}{l}\operatorname{tr} \\
\operatorname{tr}\end{array}$ & - \\
\hline $\begin{array}{l}W-16 \\
W-16\end{array}$ & $\begin{array}{l}4308.6 \\
4318\end{array}$ & $\begin{array}{l}\text { Foreshore } \\
\text { U. Shoref ace }\end{array}$ & & $\begin{array}{l}2 \\
2\end{array}$ & $\begin{array}{l}1 \\
1\end{array}$ & $\begin{array}{l}1 \\
1\end{array}$ & $\overline{-}$ & $\begin{array}{l}\operatorname{tr} \\
\operatorname{tr}\end{array}$ & - & $\begin{array}{l}3 \\
5\end{array}$ & $\begin{array}{l}2 \\
3\end{array}$ & $\begin{array}{l}1 \\
\text { tr }\end{array}$ & - \\
\hline $\begin{array}{l}W-7 \\
W-7 \\
W-7 \\
W-7\end{array}$ & $\begin{array}{l}4405.5 \\
4410.0 \\
4417.5 \\
4418.9\end{array}$ & $\begin{array}{l}\text { Estuartine } \\
\text { Estuarine } \\
\text { Swamp } \\
\text { Alluvial Channel }\end{array}$ & 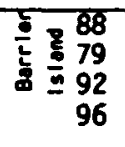 & $\begin{array}{l}4 \\
4 \\
3 \\
1\end{array}$ & $\begin{array}{l}\overline{-} \\
-\end{array}$ & $\begin{array}{l}\text { tr } \\
- \\
-\end{array}$ & $\begin{array}{l}- \\
\overline{-} \\
-\end{array}$ & $\begin{array}{l}- \\
- \\
-\end{array}$ & $\begin{array}{l}\overline{-} \\
- \\
-\end{array}$ & $\begin{array}{l}2 \\
2 \\
3 \\
3\end{array}$ & $\begin{array}{l}\operatorname{tr} \\
\operatorname{tr} \\
\operatorname{tr} \\
\operatorname{tr}\end{array}$ & $\begin{array}{l}6 \\
15 \\
2 \\
\operatorname{tr}\end{array}$ & $\begin{array}{l}\overline{-} \\
\overline{-} \\
\overline{-}\end{array}$ \\
\hline $\begin{array}{l}W-7 \\
W-7\end{array}$ & $\begin{array}{l}4419.5 \\
4431.3\end{array}$ & $\begin{array}{l}\text { U. Shoreface } \\
\text { U. Shoref ace }\end{array}$ & $=94$ & $\begin{array}{l}2 \\
3\end{array}$ & $\overline{-}$ & $\overline{-}$ & $\overline{-}$ & $\overline{2}$ & $\overline{-}$ & $\begin{array}{l}2 \\
2\end{array}$ & 2 & $\begin{array}{l}\text { tr } \\
\text { tr }\end{array}$ & $\overline{-}$ \\
\hline \multicolumn{14}{|c|}{ Outcrop } \\
\hline $\begin{array}{l}\text { GM } \\
G M \\
G M \\
G M\end{array}$ & $\begin{array}{l}0 \\
10 \\
52 \\
65\end{array}$ & $\begin{array}{l}\text { Fluvial channel ss } \\
\text { Fluvial channel ss } \\
\text { Continental sits. } \\
\text { Fluvial ss }\end{array}$ & $\begin{array}{l}93 \\
97 \\
96 \\
97\end{array}$ & $\begin{array}{l}2 \\
\operatorname{tr} \\
\operatorname{tr} \\
\operatorname{tr}\end{array}$ & $\begin{array}{l}- \\
-\end{array}$ & $\begin{array}{l}\text { tr } \\
- \\
\text { tr } \\
\text { tr }\end{array}$ & $\begin{array}{l}1 \\
- \\
\operatorname{tr}\end{array}$ & $\begin{array}{l}- \\
- \\
-\end{array}$ & $\begin{array}{l}- \\
- \\
-\end{array}$ & $\begin{array}{l}3 \\
2 \\
2 \\
1\end{array}$ & $\begin{array}{l}1 \\
\operatorname{tr} \\
\operatorname{tr} \\
\operatorname{tr}\end{array}$ & $\begin{array}{l}\operatorname{tr} \\
1 \\
2 \\
2\end{array}$ & \\
\hline
\end{tabular}


Valley fill sandstone in the Bell Creek reservoir may immediately overlay the barrier island sandstone (less common case) or may be separated by shaley or silty lagoonal, estuarian, or low-energy, inactive alluvial silty channel deposits. This indicates possible local hydraulic communication between the two most distinctive productive and potentially productive groups of Muddy sandstones and differs from earlier models that present them as parts of the reservoir continuously separated by impermeable (lagoonal) facies without hydraulic communication. Both situations are illustrated by graphic correlation of facies in adjacent wells (P-2 and W-7) with similar log characteristics but different lithologies and stratigraphy as derived from new core interpretations. As much as 8 feet ( 30 percent) of the barrier top sandstone observed in we $11 \mathrm{P}-2$ may have been lost in we $11 \mathrm{~W}-7$ because of valley incision. Similarity of log response patterns in these two wells illustrates how difficult or even misleading an attempt to interpret 1 ithologies and facies from logs in these wells would be without sedimentological models derived from analyses of available cores. Another example of potential misinterpretation is illustrated in well C-4 (Fig. 8) where the top part of a cored barrier island section, sedimentologically interpreted as upper shoreface, produced deep "back-kick" on both the coregamma and the gamma ray log run in the well. This "shale-kick" might have suggested division of two sandstone bodies by a lagoonal deposit. Petrographic examination of samples taken to explain this anomaly revealed abundant, thin, horizontally oriented argillaceous laminae separating relatively clean sandstone intercalations. The permeability of this section of barrier island sandstone was significantly reduced.

Lithogenetic cross section (A-A') (Fig. 8), parallel to the structural strike of the Muddy formation in SW-NE direction, was constructed to document the interrelationship between barrier island and valley fill deposits along the northwest side of the TIP area in sections 27, 22, and 23. Gamma ray, SP, and resistivity wireline log signatures from 16 wells and sedimentologic core descriptions from six wells were used for geological correlation of the major lithogenetic units. The log responses were geologically calibrated in several of the wells with genetic unit cores from the same well (with an estimated error of 0.5 foot). Calibration included major facies changes, observed unconformities, and comparison of subsurface gamma ray log response to core gamma ray log response (where available). 


\section{A}

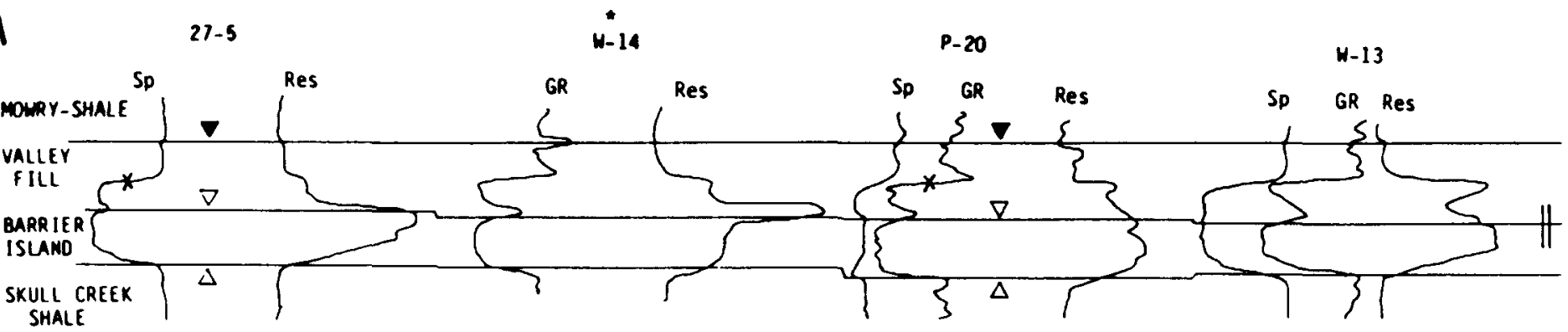

SHALE
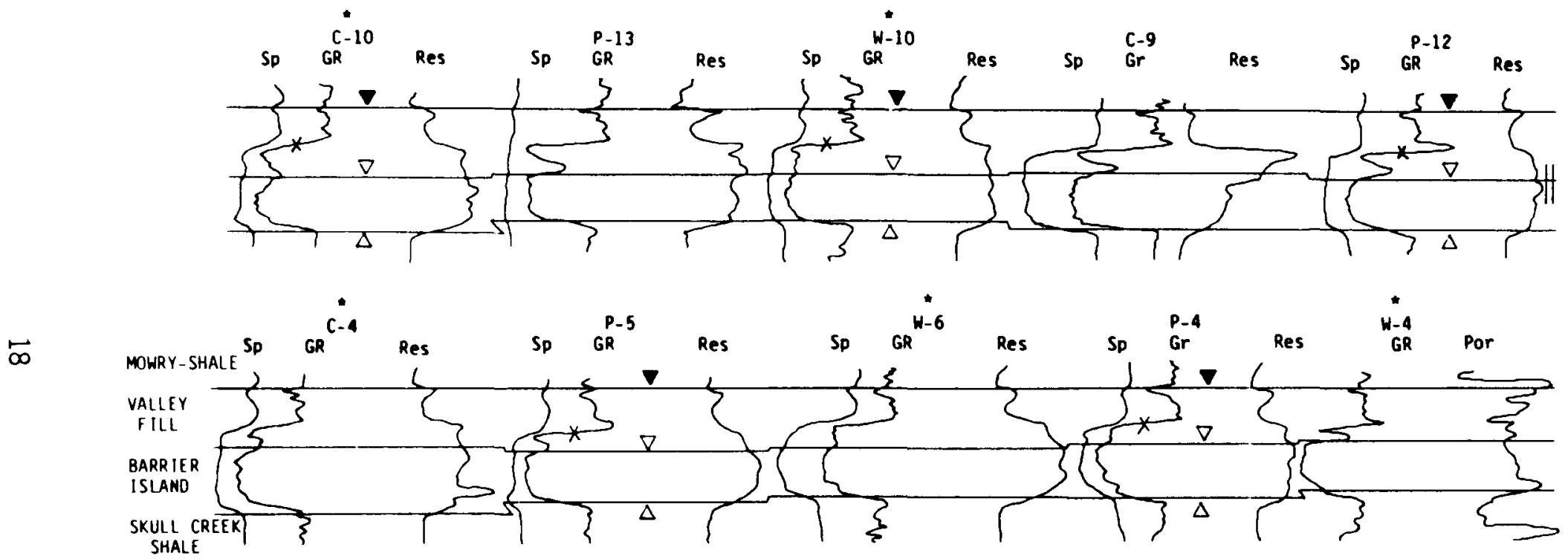

II break in cross-section

$\star$ Core control in these wells.

$\triangle$ base of Muddy formation and barrier island unit.

$\nabla$ top of barrier island unit.

$x$ top of Muddy sandstones complex (barrier island and valley fill).

$\checkmark$ top of Muddy formation

FIGURE 8. - Log and core based diagranatic 1ithogenetic cross-section A-A' interpreting relationship of major genetic units of Muddy formation in TIP area, Bell Creek field. 
The datum for stratigraphic cross-section $\mathrm{H}-\mathrm{H}^{\prime}$ is the marker commonly used to indicate the top of the Muddy formation. This marker is constant on SP and gamma ray logs over the area. The base of barrier island sandstone facies conformably overlies the Sku11 Creek marine shale with a characteristic change of log signature. The base of the Muddy formation is the base of the sandstone. Both the top and the base of Muddy can be identified on original logs within 2 feet without core control.

The top of barrier island sandstones was identified in cores as a disconformity between barrier sandstones and valley fill deposits. This contact is not always readily identifiable on logs although the resistivity log commonly shows an increase of rock conductivity upward within the valley fill deposits in contrast to the usually low conductive (oil-rich) barrier island complex. Separation of these two genetic units is almost impossible on the basis of the SP log alone. More detailed lithologic changes are seen on gamma ray and porosity logs.

The SP and resistivity $\log$ profiles in we $11 \mathrm{~W}-10$ in cross-section A-A' (Fig. 8) show similar responses in barrier island and overlying valley fill sandstones. The porosity log (not shown), however, indicates a lower average porosity in the valley fill section allowing separation of the two lithogenetic units.

Cross-section $A-A^{\prime}$ runs parallel to the general elongation of the barrier and shows only a 20 percent variation in barrier island thickness (northeast thickening) (Fig. 8 and table 2). Total thickness of the Muddy formation, varies from 42.5 to 49.0 feet in cross section $A-A^{\prime}$. The slight increase of barrier thickness is inversely proportional to total valley fill thickness (table 2). The average thickness of valley fill sandstones overlying the barrier sandstones is 8 feet, but variation in thickness may reach 65 percent with significantly lower values toward the northeast (table 2 and Fig. 8). The top part of the Muddy formation is developed predominantly as silty and clayey valley fill facies. Distribution of productive facies within the barrier body can be determined, at this time, only in wells where cores have been geologically interpreted. Inferring of lateral continuity and vertical distribution of individual facies in noncored wells requires further work and a more comprehensive method of log analyses. 
TABLE 2. - Cross section H-H' formation thickness comparison based on interpretation of gamma ray, SP, and resistivity logs and avallable cores. (in feet)

\begin{tabular}{|c|c|c|c|c|c|}
\hline & Well No. & $\begin{array}{l}\text { Barrier island } \\
\text { sandstone }\end{array}$ & $\begin{array}{l}\text { Valley fill } \\
\text { sandstone }\end{array}$ & $\begin{array}{c}\text { Total } \\
\text { valley fill }\end{array}$ & $\begin{array}{c}\text { Total } \\
\text { Muddy } \\
\text { formation }\end{array}$ \\
\hline \multirow[t]{15}{*}{ SW } & 27.5 & 17.5 & 9.0 & 25.0 & 42.5 \\
\hline & $W-14^{1}$ & 18.0 & 10.0 & 25.5 & 43.5 \\
\hline & $P-20$ & 20.0 & 8.0 & 25.5 & 45.5 \\
\hline & $W-13$ & 18.0 & 10.0 & 28.0 & 46.0 \\
\hline & $C-10^{1}$ & 20.0 & 11.0 & 29.0 & 49.0 \\
\hline & P-13 & 20.5 & 7.0 & 25.0 & 45.5 \\
\hline & $W-10^{1}$ & 21.0 & 10.0 & 24.0 & 45.0 \\
\hline & $C-9$ & 20.0 & 7.0 & 24.0 & 44.0 \\
\hline & $P-12$ & 19.5 & 6.0 & 25.0 & 44.5 \\
\hline & $C-4^{l}$ & 21.0 & 5.5 & 26.0 & 47.0 \\
\hline & $W-9$ & 20.5 & 7.5 & 24.0 & 44.5 \\
\hline & $P-5$ & 21.0 & 7.5 & 21.5 & 43.5 \\
\hline & $W-6^{l}$ & 20.0 & 9.5 & 23.0 & 43.0 \\
\hline & $C-3$ & 22.0 & 5.0 & 20.0 & 44.0 \\
\hline & $P-4$ & 21.5 & 5.5 & 22.0 & 43.5 \\
\hline NE & $W-4^{1}$ & 21.0 & 4.0 & 21.5 & 42.5 \\
\hline
\end{tabular}

${ }^{1}$ Core control on these wells.

Relfef on the disconformity at the top of the barrier is minimal in crosssection $A-A^{\prime}$. However, small-scale, steeper incisions locally reducing more of the barrier island sequence cannot be entirely ruled out between cored, geologically interpreted wells. We can conclude that, so far, in Unit $A$ at least two scales and geometries of valley incisions into the best productive barrier island sandstones have been documented: a narrow, steep, and deep type (Figs. 5 and 6 ) and a broad type with only moderate relief (Fig. 8 ). Geologic interpretation of cross-sections forming a fence diagram of flow units is underway to obtain a spatial image of reservoir geometry in the TIP area for simulation studies.

Relatively low-permeability sediments prevail in most valley infillings at Bell Creek as exemplified by petrophysical data related to core-derived 
interpretation of brackish marine to continental facies above a major unconformity at 4,547 feet in well 26-7 (table 3). The low ratio of vertical to horizontal permeability $(\mathrm{Kv} / \mathrm{Kh}=0.3$ to 0.6$)$ is characteristic for valley fills overlying the most productive barrier island facies that have a $\mathrm{Kv} / \mathrm{Kh}$ ratio of about 0.7 for upper and middle shoreface and about 1.0 for foreshore facies (table 3 ). These numbers indicate some tendency for retardation of vertical fluid displacement within the valley fill deposits. Also, because of the similar log characteristics and comparable horizontal permeability values, the upper shoreface and foreshore barrier island facies have been characterized, to date, as one flow unit. The $\mathrm{Kv} / \mathrm{Kh}$ ratio in well 26-7 (table 3 ) indicates, however, significant differences in flow potential of these two facies.

Portions of the barrier immediately underlying the unconformity at the base of the valley fills are at least locally strongly affected by diagenetic processes. The diagenesis probably resulted from exposure to an oxygenated environment in which fresh and marine waters interacted to form secondary

TABLE 3. Petrophysical properties of barrier island and nonbarrier facies in Well 26-7. Note variation of $K_{v} / K_{h}$ ratio.

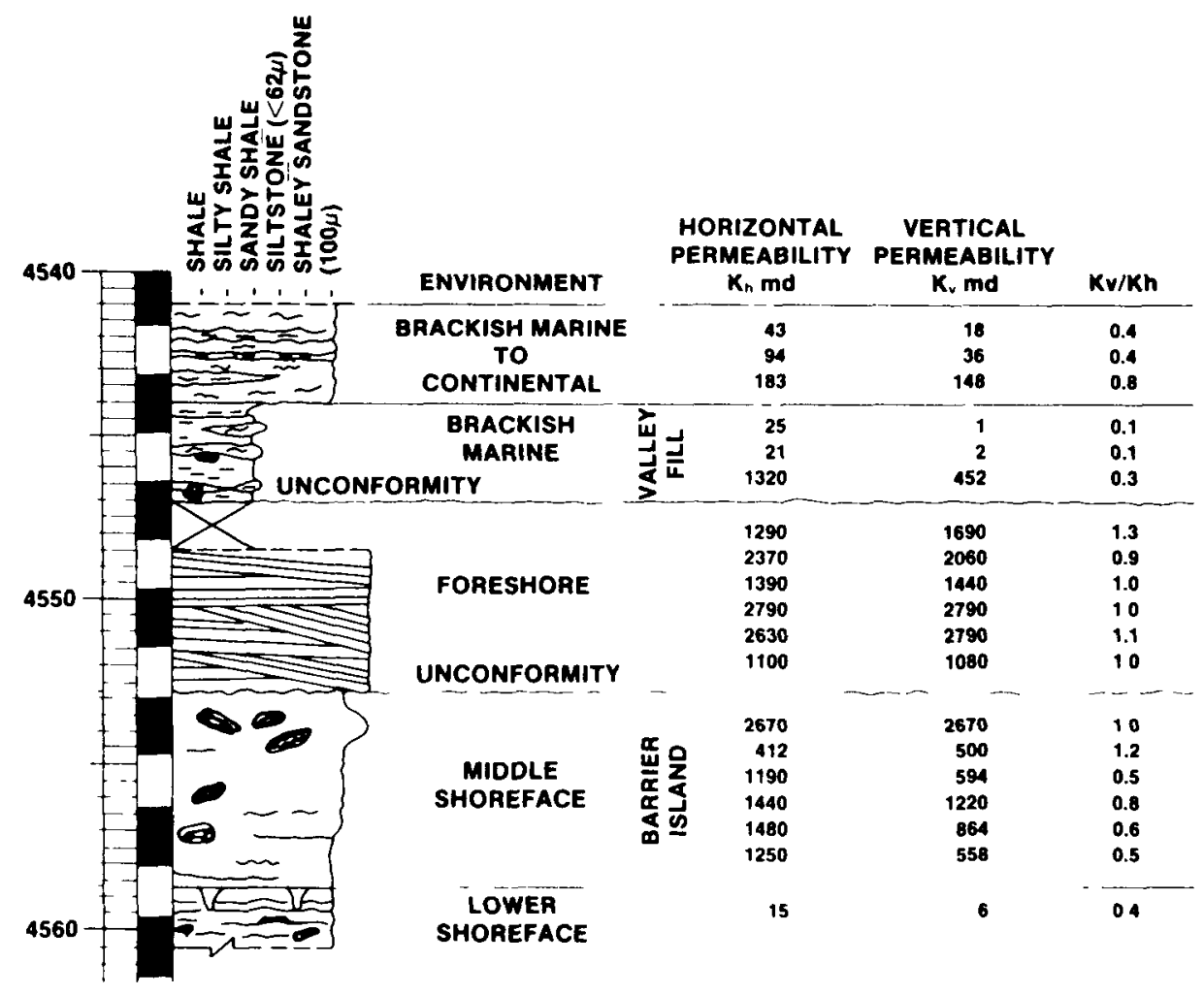


clays and cements. ${ }^{6-7}$ Quantitative results of $X$-ray diffraction examination of samples from Bell Creek cores are presented in table 1 and figure 7. Postdepositional diagenetic alterations developing predominantly as authigenic clays that cement pores and reduce pore throats have been documented in the first series of 40 thin sections. Thin ( 1 to 2 foot) layers of enhanced porosity and permeability strongly contrasting with adjacent layers were also identified in some cores. Preliminary study indicates that a possible cause for the development of high-permeability "channels" could be "undercompaction." The scarcity of petrographic data from available scattered cores sampled in Bell Creek makes spatial mapping of diagenetic influences difficult.

Transmissivity and continuity of fluid flow in the Bell Creek reservoir are affected strongly by depositional, erosional, and diagenetic factors and are further complicated by tectonization of the Muddy formation.

Extensive small-scale tectonic faulting (usually less than 30 feet of vertical displacement) has been documented in production Unit " $A$ " of the Bell Creek reservoir. The ratio of vertical displacement to the net pay varies from 0.5 to 1.5 , indicating the possibility of local restriction or disconnection of fluid flow. Construction of a structural map of the TIP area is underway. Two structural cross-sections along the strike and dip of the Muddy formation are presented in figure 9. The influence of tectonization on ofl production and propagation of injected fluids from primary, secondary, and tertiary production data; waterflood performance; and results of falloff and tracer tests are being studied.

Because of the geological complexity revealed in the 17 cores examined in the study area, and problems with reliable differentiation of the barrier and nonbarrier sediments (valley fill facies) on logs, the spatial mapping of barrier island architecture is difficult. A more detailed study is underway on the distribution of barrier island facies within Bell Creek, Unit $A$, their stacking pattern, variation in depths of cuts, types of infillings, their effect on localization of diagenesis, and the effect of faulting on production.

Based on the present state of geological interpretation, the major elements of the improved geological/engineering model comprising depositional, diagenetic, and tectonic heterogeneities documented in the Bell Creek, Unit $A$, 


\section{Bell Creek Oil Field, Unit A}

Structural Section Across TIP Area

Parallel to Dip of Muddy Sandstone *
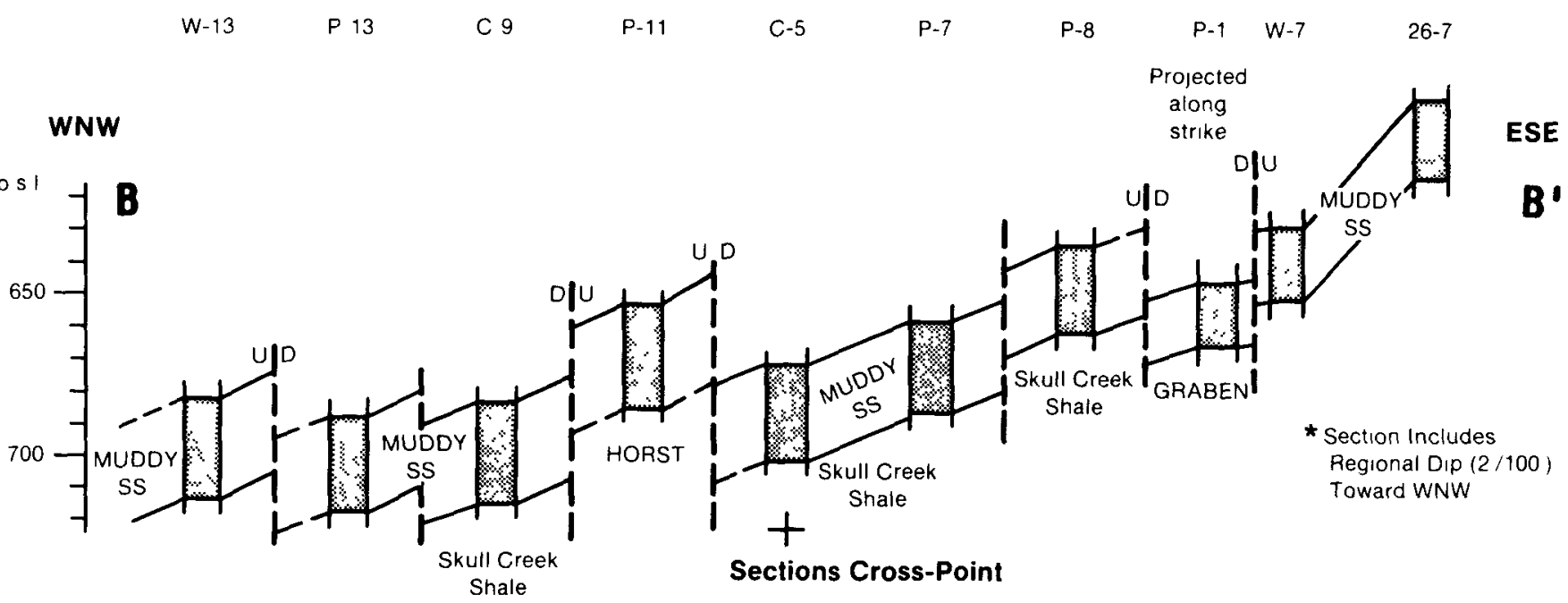

Structural Section Across TIP Area

Parallel to Structural Strike of Muddy Sandstones

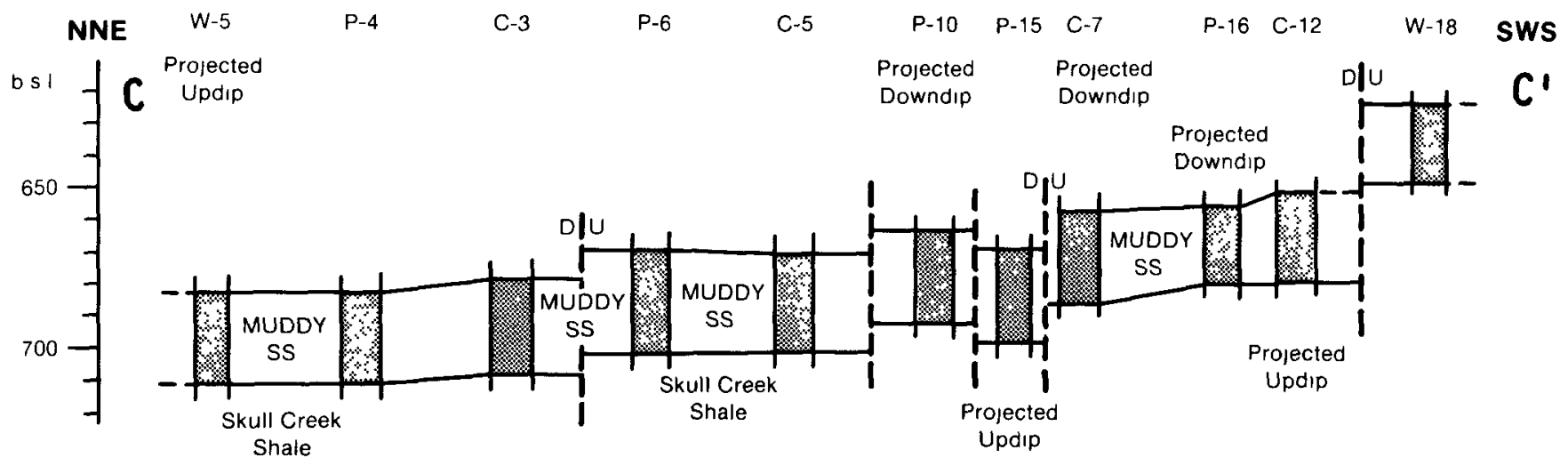

FIGURE 9. - Structural cross sections (B-B') and (C-C') of of Muddy formation sandstones in Unit $A$, Bell Creek field. 
TIP area have been summarized, and an initial attempt to scale the heterogeneities has been made (table 4). The heterogeneities listed in table 4 were mostly documented previous $1 y^{4}$ and were not considered in earlier Bell Creek reservoir models. Large-scale (L) heterogeneities extending for miles may affect the entire field or production unit. Medium-scale (M) heterogeneities affect predominantly the interwell area or groups of wells and extend to a distance of hundreds or thousands of feet. Smal1-scale (S) heterogeneities may affect fluid flow patterns in a distance of feet or tens of feet. The scale of expected fault-related fracturing of the Muddy reservoir is still unknown ("U" heterogeneity). Spatial mapping of the type and scale of major heterogeneities $(L)$ requires a more regional geological interpretation.

\section{RESERVOIR QUALITY OF THE BARRIER ISLAND COMPLEX Reservoir Definition}

Barrier island and related nonbarrier facies documented in Be11 Creek cores can be grouped, from the engineering point of view, into three classes according to the decreasing turbulence of the environment of deposition (table 5).

Class ' $A$ ' sediments, when not severely affected by diagenesis, have the best reservoir properties and have permeabilities in the range of hundreds and thousands of millidarcies, whereas in class ' $B$ ' deposits, permeabilities rarely exceed hundreds of millidarcies. Nonproductive sediments of class ' $C$ ' usually have low permeabilities ranging from near zero to tens of millidarcies. The lateral extent and continuity of facies of the three classes can be precisely to roughly predicted from the depositional models. In the central part (TIP pilot area) of Unit $A$ in Bell Creek field, a poor quality class ' $B$ ' and nonproductive facies class ' $C$ ' are significantly thinner than the high-quality Middle Shoreface and Foreshore facies (class ' $A^{\prime}$ ). The barrier core (central portion of the barrier) has better reservoir quality potential than distal parts of barrier-front and back-barrier, where thinner and lower energy facies intercolate with nonproductive members of adjacent depositional environments. Thus, oil productivity in the "barrier core" should be directly proportional to the total thickness of barrier deposits 
TABLE 4. - Summary of documented reservoir heterogeneities in Bell Creek, unit "A" cores; major elements of improved geological/engineering model and their preliminary scaling

A. DEPOSITIONAL HETEROGENEITIES

Scale $^{1}$

(1) Changing laterally lithostratigraphic patterns of facies

- within one complete barrier sedimentary cycle

- between stacked incomplete sedimentary barrier cycles

$L / M$

$L$

M

M

$M / S$

$L / M$

$L / M$

$M$

$\mathbf{L}$

$M$

$L / M$

M

$M$

$M / S$

- dominantly kaolinite

- forms coatings on framework grains and blocks pore throats

- effect enhanced by compaction

$M$

$S$

- one of the major control of $\phi$ and $k$ in

barrier sandstone

$L / M$

$S / M$

(5) Undercompacted zones

- Process poorly understood. Diagenetic origin explains 1-2 foot thick intervals with as much as 11,000 md permeability. Lateral extent not yet documented)

- can reverse expected $\phi$ and $k$ trends

U

$S$

$S / M$

$S / M$

$S$ 
TABLE 4. - Summary of documented reservoir heterogeneities in Be 11 Creek, unit "A" cores; major elements of improved geological/ engineering model and their preliminary scaling-Continued

\section{STRUCTURAL (TECTONIC) HETEROGENEITIES}

\section{$\underline{\text { Scale }}^{1}$}

(7) Influence of structural blocking and faulting on hydraulic "chocking" or disconnection of fluid flow

- different vertical displacement and tilting of tectonic blocks

- Fading of faults in short distances

- Fault related fracturing of Muddy reservoir

$U / M$

M

$M / S$

U

$\checkmark$ - Large scale affecting entire field or productive unit (in miles).

$M$ - Medium scale affecting predominantly the interwell area or group of wells (hundreds and thousands of feet).

S - Small scale affecting local fluid flow pattern in interwell area (in feet or tens of feet).

$U$ - Unknown scale to date.

Sku11 Creek shale and locally unconformably overlain by continental brackish and shallow marine valley fills (class ' $B$ ' and ' $C$ ') and/or marine deposits (class ' $C$ '), as shown in figure 5 and table 6.

because class ' $A$ ' sediments predominate in the geological sequence. Barrier deposits are apparently conformably underlain by marine (class ' $C$ ')

Productivity of individual wells and efficiency of water and chemical injection within the barrier core will also depend on spatial variation in site-specific transmissivity and hydraulic connectivity between groups of wells resulting from diagenetic alterations addressed later, and on local faulting. Engineering and production data as well as core, log, and outcrop interpretations indicate significant geological complexities in the study area of Bell Creek field.

\section{Reservoir Framework and Quality}

The construction of the geological model of the barrier island deposit at Bell Creek was initiated by constructing the reservoir framework of the bar deposit. More detailed investigation of the stratigraphy, lithology, sedimentary and biogenic structure, grain size distribution, and cementation distribution of the different bar facies was made from the examination of 17 cores. 
TABLE 5. - Classification of productive and non-productive facies (documented In cores) of muddy sediments in Bell Creek reservoir

\begin{tabular}{|c|c|c|c|c|}
\hline CLASS & & FACIES & $\begin{array}{l}B \text { - BARRIER } \\
\text { NB - NON-BARRIER }\end{array}$ & \\
\hline$A$ & 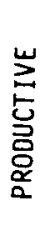 & $\begin{array}{l}\text { FORESHORE } \\
\text { AEOLIAN } \\
\text { AEOLIAN FLAT } \\
\text { UPPER SHOREFACE } \\
\text { WASHOVER } \\
\text { CHANNEL CUT FILL } \\
\text { MARINE VALLEY FILL }\end{array}$ & $\begin{array}{l}\text { (UPPER/LOWER) } \\
\text { (TAIL \& CORE) } \\
\text { (HIGH ENERGY) } \\
\text { (HIGH ENERGY) }\end{array}$ & $\begin{array}{l}-B \\
-B \\
-B \\
-B \\
-B \\
-N B \\
-N B\end{array}$ \\
\hline 8 & $\sum_{\stackrel{5}{亏}}$ & $\begin{array}{l}\text { MIODLE SHOREFACE } \\
\text { WASHOVER (INTO LAGOON) } \\
\text { MARINE VALLEY FILL } \\
\text { CHANNEL CUT FILL } \\
\text { ALLUVIAL VALLEY FILL } \\
\text { ESTUARY FILL } \\
\text { WINDBLOWN SAND IN LAGOON }\end{array}$ & $\begin{array}{l}\text { (LOW ENERGY) } \\
\text { (LOW ENERGY) } \\
\text { (HIGH ENERGY) }\end{array}$ & $\begin{array}{l}-B \\
-B \\
-N B \\
-N B \\
-N B \\
-N B \\
-N\end{array}$ \\
\hline c & $\begin{array}{l}\frac{1}{1} \\
\frac{1}{2} \\
\frac{1}{2}\end{array}$ & $\begin{array}{l}\text { LOWER SHOREFACE } \\
\frac{\text { LAGOON FILL }}{\text { ALLUVIAL VALLEY FILL }} \\
\text { SWAMP \& MARSH } \\
\text { MARINE TRANSITION TO THE BARRIER }\end{array}$ & (LOW ENERGY) & $\begin{array}{l}-B \\
-\quad N B \\
-\quad N B \\
-N B\end{array}$ \\
\hline
\end{tabular}

${ }^{1}$ Dominant facies are underlined.

TABLE 6. - Documented prevailing stacking patterns of Muddy sediments in central part of Unit A, Bell Creek field

\begin{tabular}{|l|l|l|l|l|}
\hline \multicolumn{2}{|c|}{ COMMON } & \multicolumn{2}{c|}{ LESS COMMON } \\
\hline & & $C$ & & \\
\\
\end{tabular}

$A=$ Best reservoir-quality sandstone facies.

$B=$ Poor reservoir-quality sandstone facies.

$\mathrm{C}=$ Nonreservoir quality facies. 
Sedimentary facies identified in cores were correlated laterally, as far as practicable, using typical responses of gamma ray, spontaneous potential, resistivity, sonic, and density logs. These "core-calibrated log responses" provided the basis for maps and cross-sections used to describe the fluid flow properties in the barrier island sandstones and associated facies.

A structure contour map on the top of the Muddy sandstones (Fig. 10) indicates that the top of the sandstone generally dips to the northwest at the rate of about 90 to $100 \mathrm{ft} / \mathrm{mile}(17$ to $19 \mathrm{~m} / \mathrm{km}$ ). As indicated on the isopach map (Fig. 11), the maximum thickness of the barrier deposit is about 29 feet (8.84 $\mathrm{m}$ ) in the central part of the study area. Sharp flexures occur in the contours in both the structure and the isopach maps in certain parts of the study area. The isopach map of gross barrier sandstone also indicates variations in the sandstone thickness along the sharp flexures which may reflect local structural or stratigraphic features. More detailed work is needed to determine the genesis of these features. Possible explanations for their origin are either faults or valley incisions (cuts).

Note that the extension of some of these flexures farther to the west (Figs. 10 or 11) almost coincides with the flexures in the western boundary of production Unit $A$, which are interpreted as deep valley cuts into barrier island deposits, as shown in figures 5 and 6 .

Variations in the properties of the barrier island facies are indicated in two cross sections $D-D^{\prime}, E-E^{\prime}$, (locations shown in Fig. 1) constructed using gamma ray logs (Fig. 12). In the wells in these cross-sections, the gamma ray and sonic logs were calibrated using core-derived facies interpretations. Cross section E-E' is perpendicular and $D-D^{\prime}$ is parallel to the depositional strike (elongation) of the bar. In these cross-sections, only the highpermeability barrier island sandstone (consisting predominantly of foreshore and shoreface facles), low-permeability lower shoreface, and lagoonal sediments where confirmed by core descriptions are indicated. The ranges in porosity and the permeability values in the foreshore and upper shoreface sandstone facies are similar, and for this reason these two facies are combined into a single flow unit. However, additional analys is of geologic data from wells which were cored or from analogous outcrops may allow separation of middle shoreface and foreshore facies by use of logs alone. Moreover, fluctuations in the thickness of these two facies make it difficult to distinguish them on logs. 


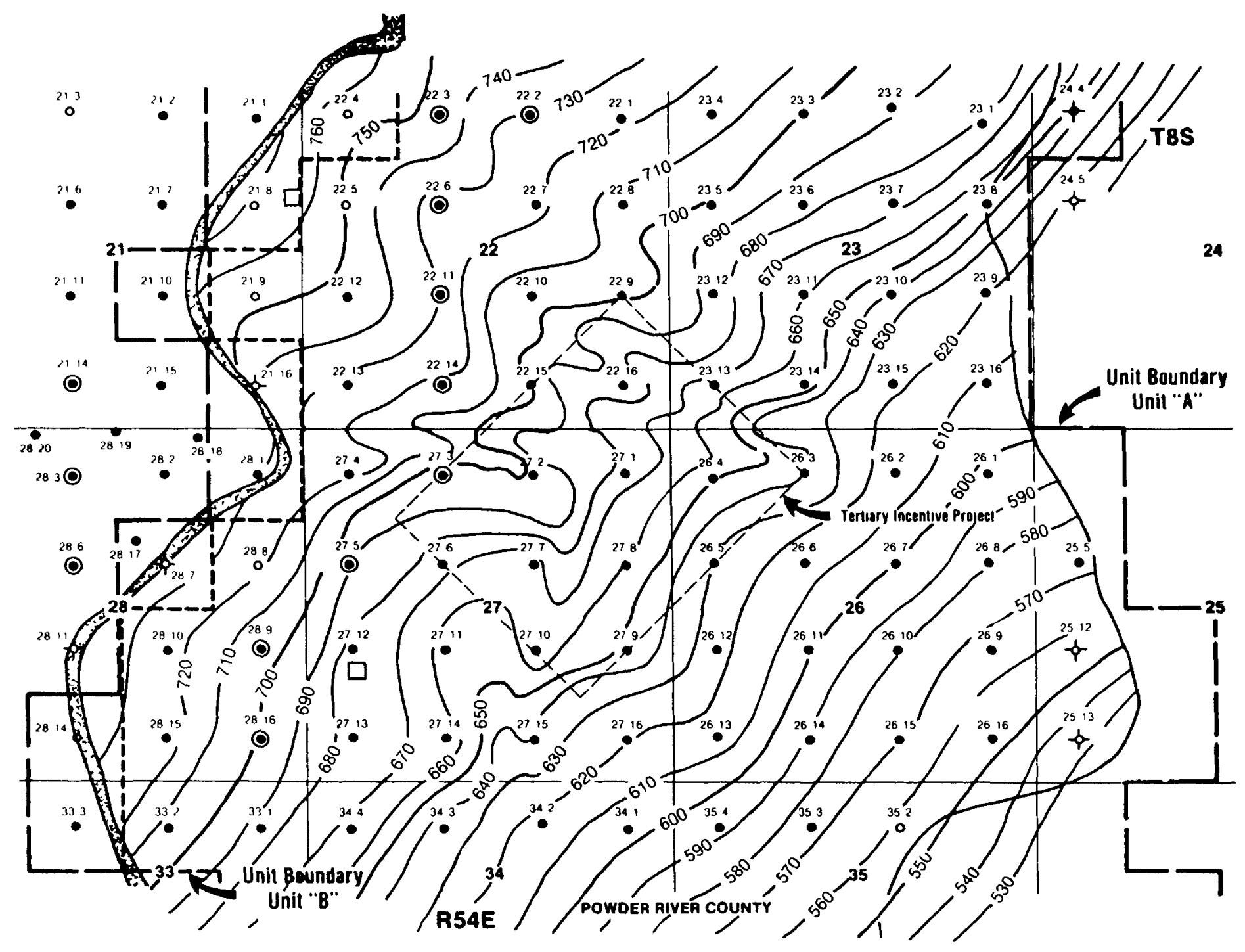

FIGURE 10. Structural contours (in feet below M.S.L.) on the top of the Muddy sandstones. C.I. $=10$ feet. 


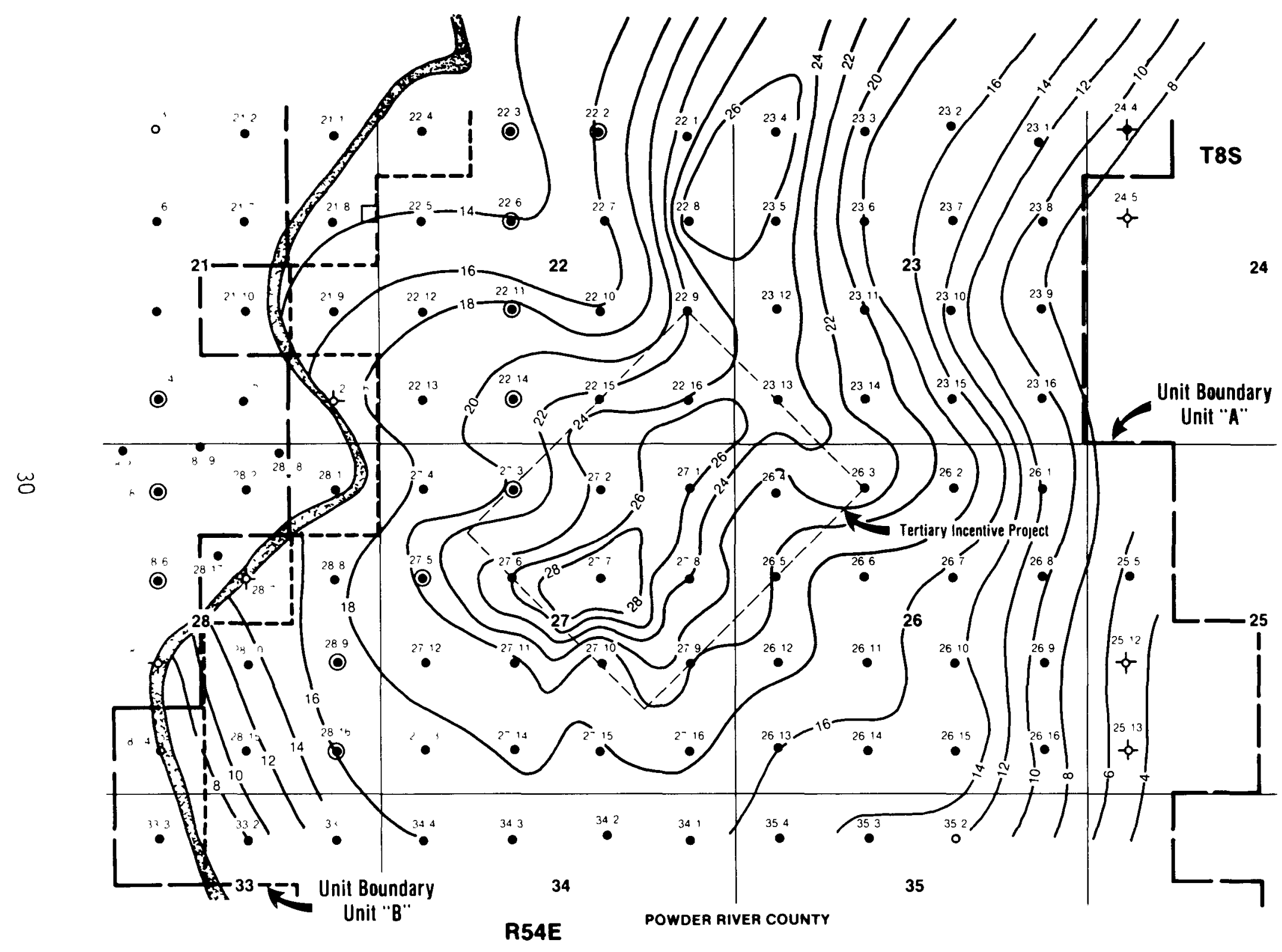

FIGURE 11. - Isopach map of the Muddy sandstones in the study area. C.I. - $10 \mathrm{ft}$. 


\section{D}

SW

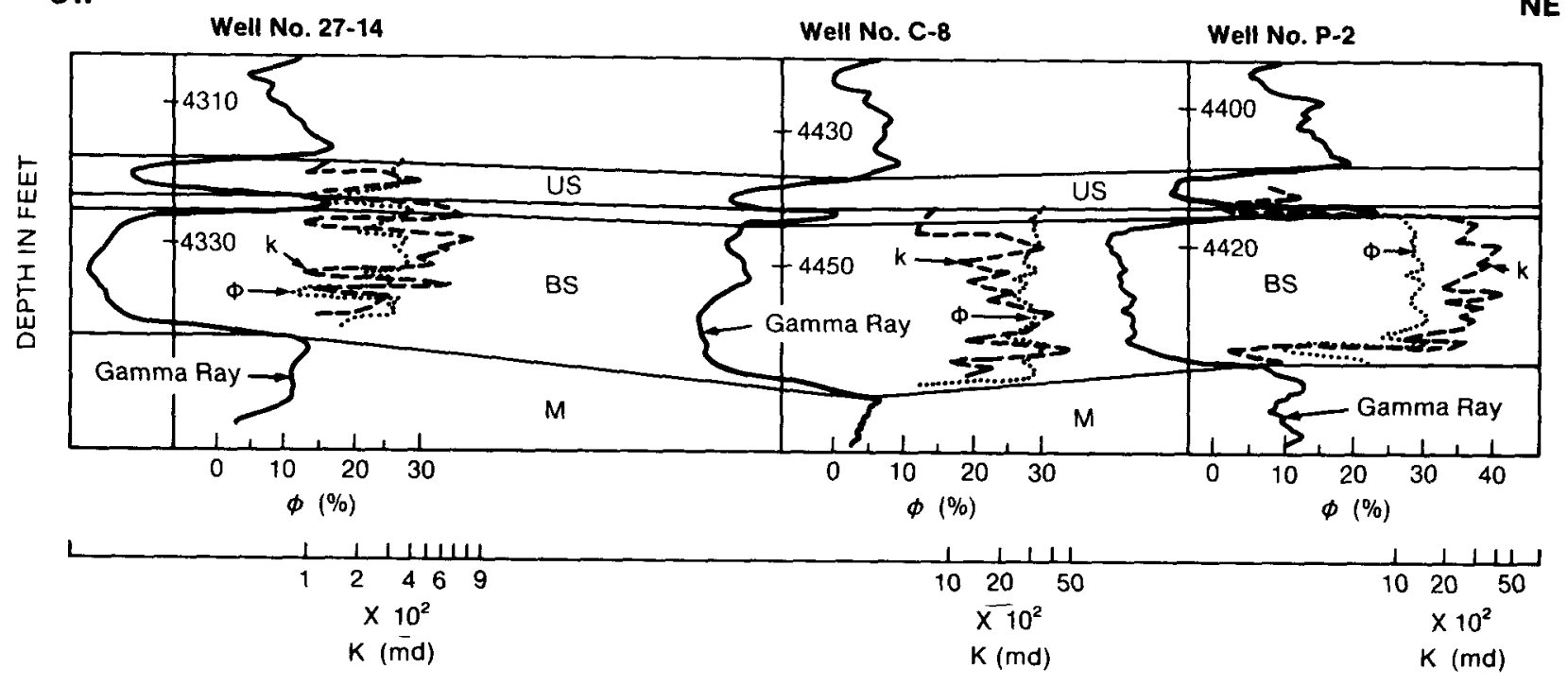

E

NW

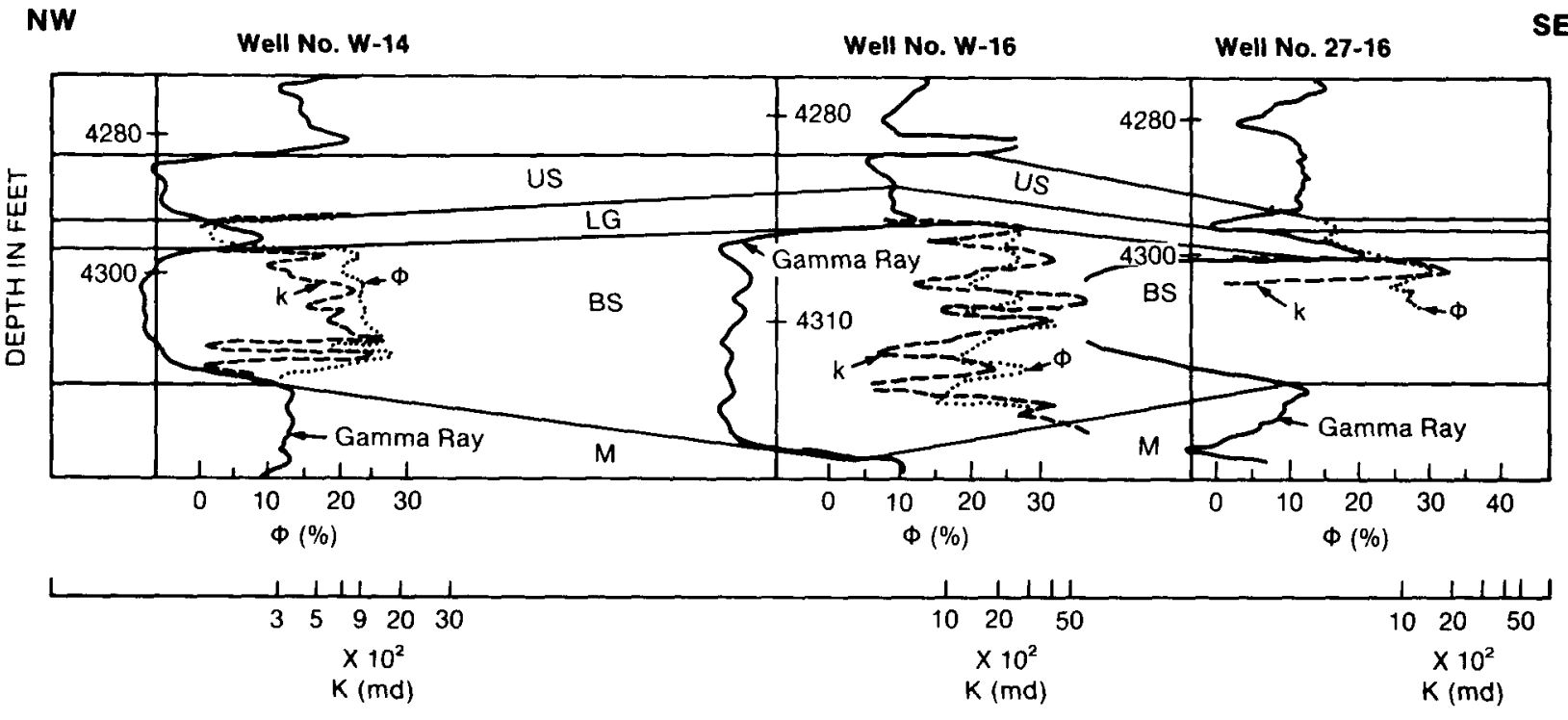

FIGURE 12. - Cross-sections (D-D') and (E-E') showing distribution of porosities and permeabilities within sandstone bodies. See figure 1 for location of cross-sections. 
Cross section D-D' indicates that the thickness and reservoir quality of the barrier island sandstone improves from southwest to northeast near the central part of the barrier deposit. Further southwest, in well 27-14, (Fig. 12) the reservoir quality in the barrier is diminished mainly because of a still higher percentage of diagenetic clay cementation through much of the productive interval.

Along section $E-E^{\prime}$, the reservoir quality is strongly influenced by cementation by different types of clays and by compaction.

\section{Petrographic Evidence}

Vertical variations in percentages of total clay, permeability, and porosity are shown in figure 13. These data are from samples of the six cored wells in stratigraphic cross sections $D-D^{\prime}$ and $E-E^{\prime}$ (Fig. 12). The data shown in figure 13 are mostly from the barrier island sandstones. Clay content and descriptive rock parameters are from 42 petrographic thin-section analyses and seven quantitative $X$-ray diffraction analyses in five wells. Air permeability and porosity data were taken from available core analyses. There is a general inverse relationship between permeability and clay percentage. Because the clay is commonly diagenetic, these characteristics vary among and within depositional facies within individual wells.

Foreshore and upper shoreface sandstones have similar petrographic characteristics. The average clay content increases with distance in most facies in wells to the west of well C-8 (Fig. 13). Among those studied, well 27-14 contains the highest percentages of clay (matrix and clay cement). In this well, total clay content averages 16 percent ( 3 percent matrix, 13 percent authigenic clay). As expected, the permeability fluctuates greatly (36 to $948 \mathrm{md}$ ).

In well $\mathrm{W}-16$, the increase in clay content of the foreshore facies from less than 1 to 4 percent over an interval of $1 \mathrm{ft}(4,312$ and $4,311 \mathrm{ft})$ is accompanied by a significant increase in permeability from 269 to $1,935 \mathrm{md}$. The increased permeability at $4,311 \mathrm{ft}$ is due to relative changes in compaction. Also, the increased compaction observed in thin sections resulted in increased packing and smaller pores. The samples at 4,308 and 4,312 ft are highly compacted resulting in lower permeability $(197,269 \mathrm{md})$ and porosity $(19.7,20.2$ percent) values, whereas the sample at $4,311 \mathrm{ft}$ is undercompacted 
Well No. 27-14

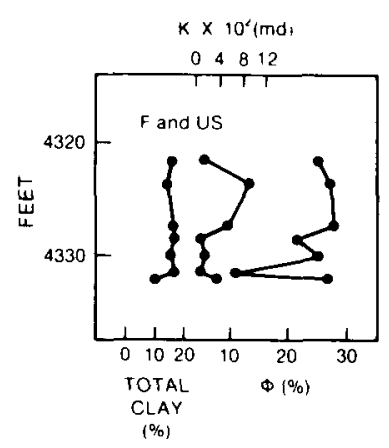

Subarkose

Moderate sorting $1-6 \%$ clay matrix Averages $13 \%$ day cement $(N=7)$
Well No. W-16

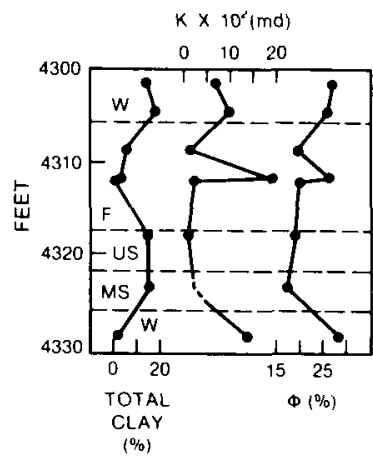

Quartzarenite and sublitharenite Moderate sorting $0-2 \%$ clay matrix Averages $9 \%$ clay cement $(\mathrm{N}=8)$
Well No. C-8

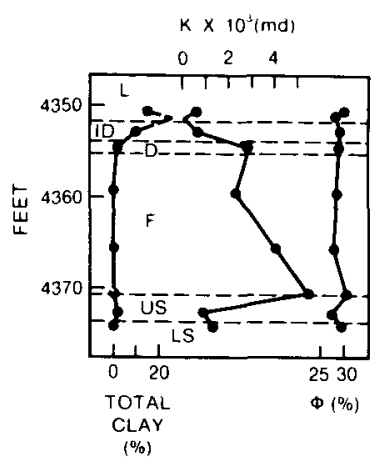

Silty mudstone, subarkose, Silty shale and subarkose and quartzarenite moderate sorting $0-3 \%$ clay matrix in sands Averages $22 \%$ clay cement in sands $(\mathrm{N}=7)$
Moderate-poor sorting $0-2 \%$ clay matrix in sanas Averages $21 \%$ clay cement in splay sands and $2 \%$ clay cement in foreshore ano shoreface sands

E

NW Well No. W-14

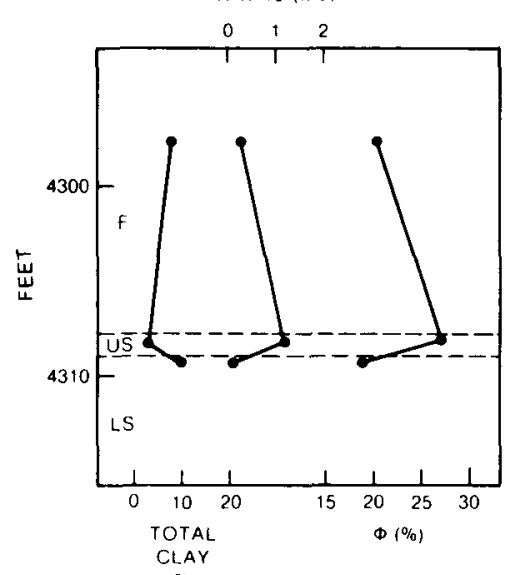

(\%)

Quartzarenite and subarkose

Poor sorting

$0-2 \%$ clay matrix

Averages $7 \%$ clay cenent $(\mathrm{N}=3)$
Well No. W-16

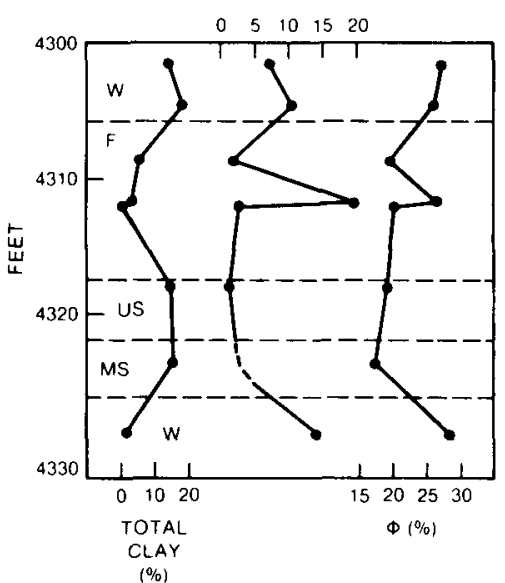

Quartzarenite and sublitharenite

Moderate sorting

$0-2 \%$ clay matrix

Averages $9 \%$ clay cement $(\mathrm{N}=8)$
Well No. 27-16

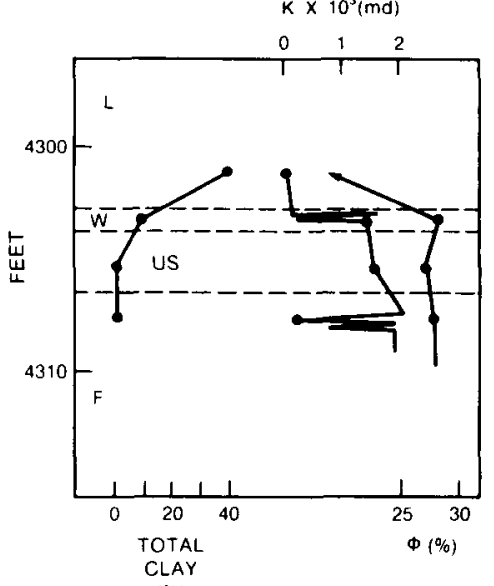

(\%)

Silty shale and subarkose

Moderate sorting

$0.5 \%$ clay matrix in sands

Averages $3 \%$ clay cement in sands $(i=3)$

FIGURE 13. - Petrographic sumary for figure 12. Abbreviations: ID, Interdune; D, Dune; F, Foreshore; US, Upper Shoreface; LS, Lower Shoreface; SF, Shoreface; S, Splay; W, Washover; L, Lagoon; MS, Middle Shoreface. 
and has a higher permeability $(1,935 \mathrm{md})$ and porosity (26.7 percent) relative to the samples above $(4,308 \mathrm{ft})$ and below $(4,312 \mathrm{ft})$. These observations indicate that although changes in percentage of total clay generally reflect permeability trends and indicate changes in depositional facies (10w "k" in lagoonal and lower shoreface facies, higher " $k$ " in upper/middle shoreface and foreshore facies), compaction may locally be the most important diagenetic heterogeneity relative to permeability. It follows that in regions severely affected by diagenesis actual permeability may not necessarily reflect depositional facies because the diagenetic overprint (authigenic clay content and compaction) may be dominant.

Petrographic data from wells in stratigraphic cross-section E-E' (Fig. 13) indicate a relatively high total clay percent ( 9 and 11 percent) in both of the more northern wells. We11 27-16 has only 3 percent clay cement, but it has as much as 5 percent clay matrix, which is nearly as much matrix as was found in samples from well 27-14 (the most argillaceous of the wells studied).

Within the wells studied, the clay percent and permeability appear to vary with depositional facies. Petrographic analysis indicates that backbarrier washover facies into the lagoonal setting and lower shoreface facies tend to contain more clay cement. Vertical trends in clay content among wells may be similar; however, interwell differences in clay content and permeability may be significant. For example, along stratigraphic cross-section E-E' (Fig. 13) permeability is less than 2,000 md in all cases. None of the cores shown in this section have permeabilities as high as those in wells $C-8$ or $P-2$. This tends to confirm a gradient of better expected production to the northeast along stratigraphic cross section D-D' (Fig. 12), and only moderate-to-low levels in a $\mathrm{N}-\mathrm{S}$ direction near the western terminus of stratigraphic cross section D-D'. This trend is also reflected in the Dykstra-Parsons coefficients (Fig. 14), the clay content (Fig. 15), and the log-derived heterogeneity index (Fig. 16) maps.

Quantitative X-ray diffraction analysis (table 1) confirms the high quartz (quartzarenite and subarkose) composition of the barrier island sandstones. Within the barrier sands, the clays exhibit a kaolinite and illite ratio of $2: 1$ and range up to a maximum of 15 percent. Smectite clays are present in all samples in only trace amounts. 


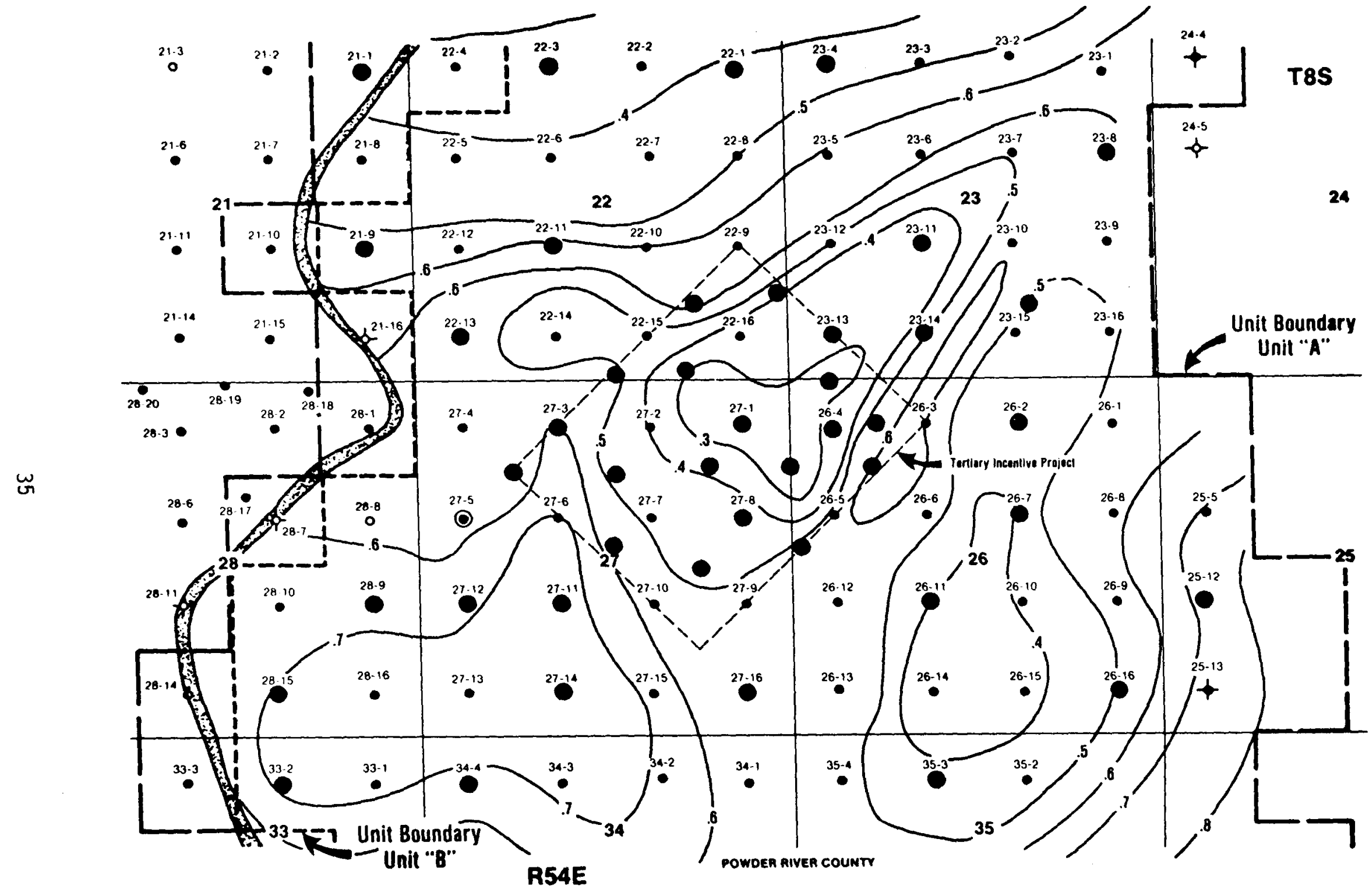

FIGURE 14. - Distribution of Dykstra-Parsons coefficients obtained from airpermeability data in the study area. Wells with permeability data are indicated by large circles. 


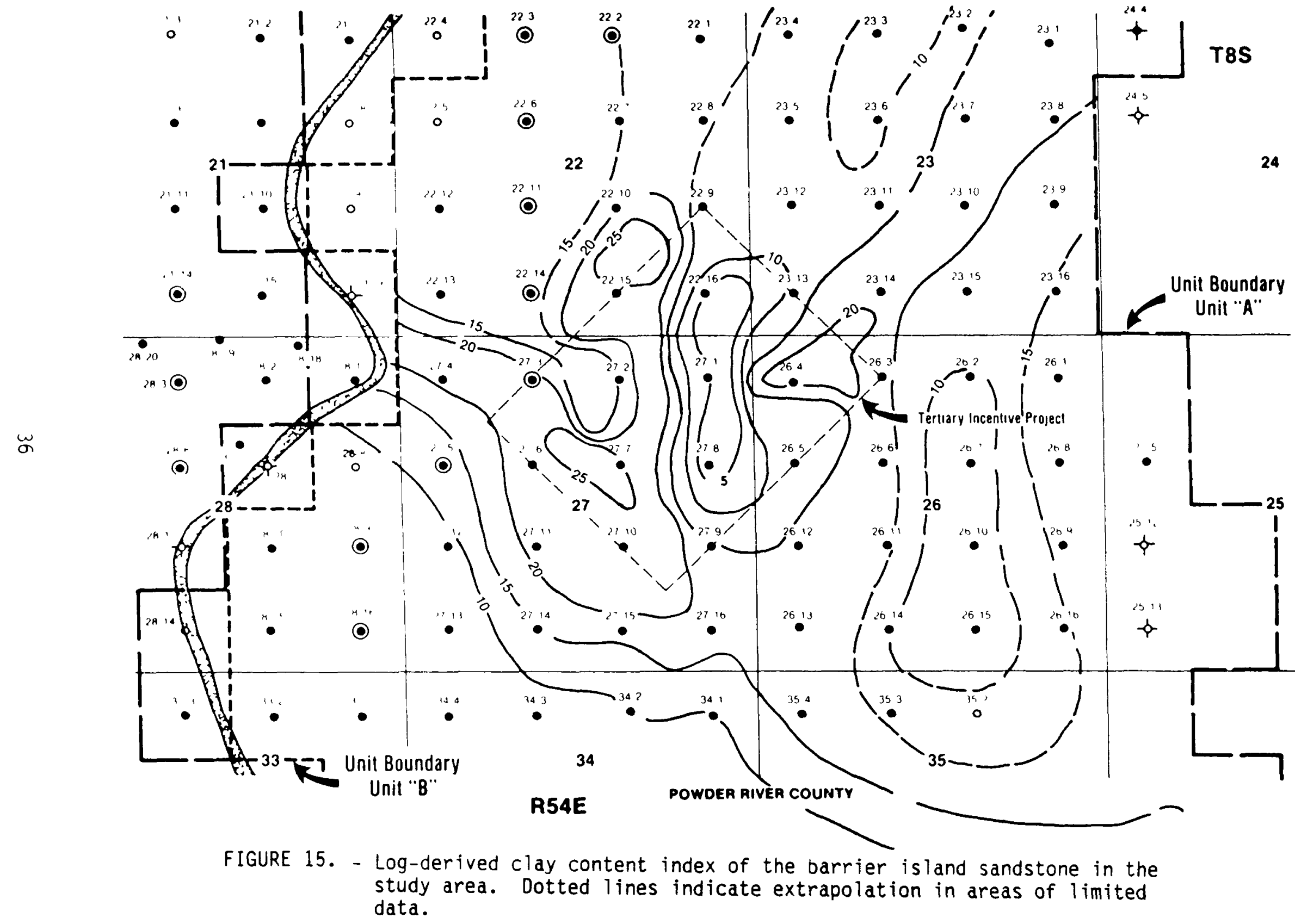




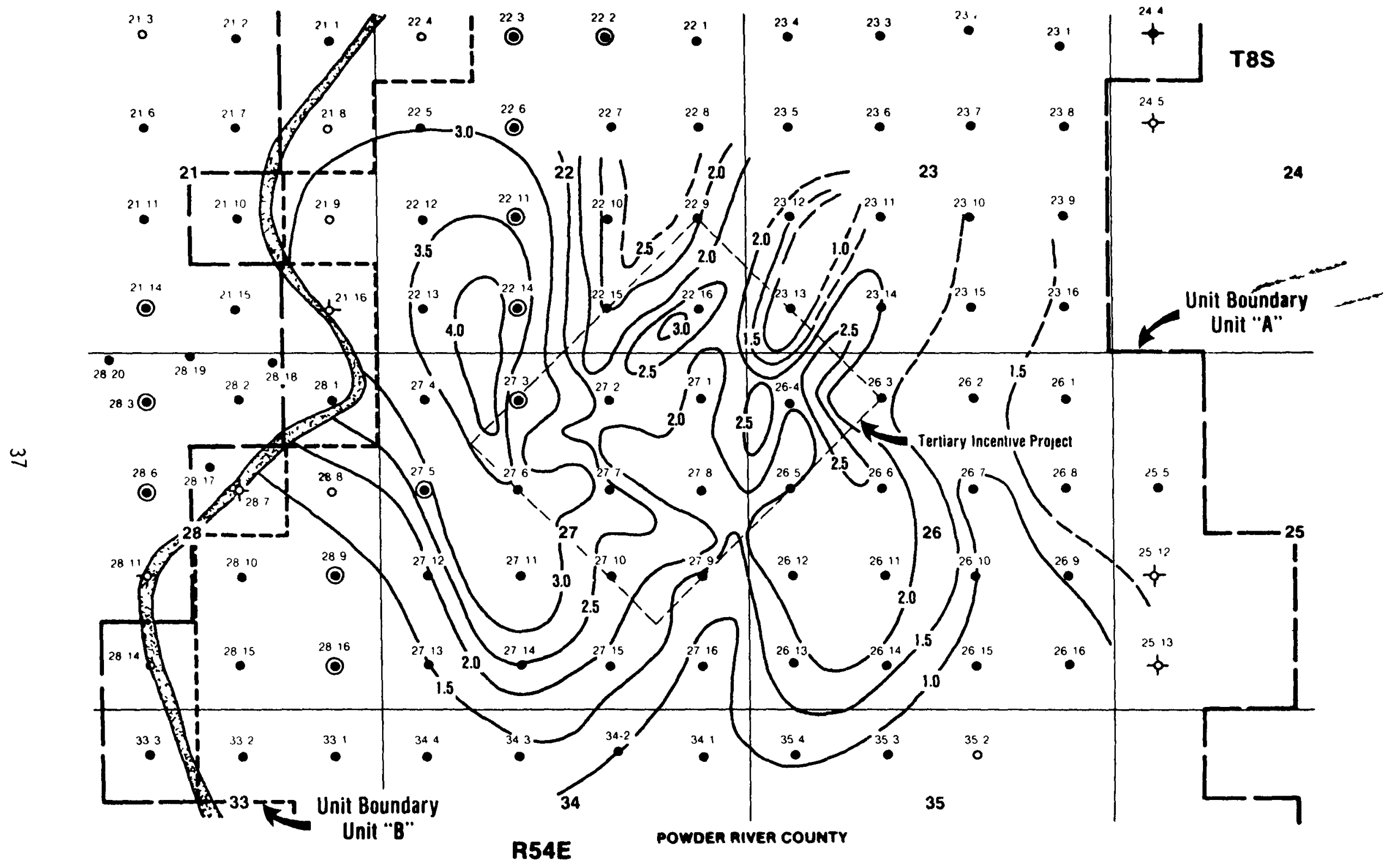

FIGURE 16. - Log-derived heterogeneity index (LHI) of the barrier is land sandstones in the study area. Sull values of the index indicate relatively cleaner reservoir sandstone. 
Similar results were obtained in a regional study by Stone ${ }^{6}$ who concluded that the clays in the shale units are dominantly illite and montmorillonite (smectite group), whereas clays in sandstones are almost exclusively kaolinite.

Most of the clays in the sandstones are diagenetic kaolinite and are derived from the decomposition of feldspars and other less stable grains such as rock fragments.

Preliminary analysis suggests that three important diagenetic events occurred following deposition of the barrier sands. The first was a strong leaching event that removed unstable grains and provided oversize pores, and the second was the creation of diagenetic clays through leaching of feldspars. Precipitation of dominantiy kaolinite cement in the barrier island sandstones resulted in a significant reduction of permeability in these zones. Calcite cemented zones have been identified in Bell Creek cores and in nearby analogous outcrops, but they have not yet been studied petrographically. The third diagenetic event was compaction, which locally provided strong variations in packing across small vertical intervals, particularly after leaching of unstable grains. These local packing varlations may greatiy influence local fluid flow rates and the amount of hydrocarbon production.

\section{DISTRIBUTION OF RESERVOIR PROPERTIES IN THE BARRIER ISLAND DEPOSIT}

Porosity and horizontal air permeability measurements from subsurface core plugs from Bell Creek field have been plotted adjacent to the gamma ray logs in the two cross-sections D-D' and E-E' (Fig. 12). The porosity and permeability profiles closely follow the general description of the quality of sandstone facies. The two cross-sections indicate evidence of strong permeability stratification resulting from the various reservoir heterogeneities. Permeability variations along these two sections suggest that the continuity of individual low-permeability streaks is limited, and that within the TIP area the reservoir heterogeneities do not subdivide the foreshore and upper/middle shoreface portions of the barrier sand into separate flow units.

The available core permeability data have been used to construct a map (Fig. 14) showing the distribution of Dykstra-Parsons coefficients of vertical 
permeability variations of the barrier sandstone in the study area. The Dykstra-Parsons plots for a few of the wells (mainly in the periphery of the study area) were rejected because the permeability distributions are obviously not log norma1, and in a few others some discretion was necessary in drawing the best straight line fit. The map should nevertheless reflect the general variation $^{10}$ in the vertical distribution of permeability of the barrier island deposit.

Fig. 14 shows that the central part of the bar deposit and the area slightly east of it are the most homogeneous (low Dykstra-Parsons values), and the area immediately southwest of the bar axis is the most heterogeneous. The area northwest of section 22 is also relatively more homogeneous.

Cross-plots of core air permeability and porosity data from the study area indicate that in most areas there is a strong correlation between porosity and permeability, except for heavily cemented areas where the relationship becomes less clear. The geometric means of available core permeability data from major productive barrier island in peripheral areas facies have been plotted in Fig. 17. Because of limited data, contours are shown only for the central part of the study area. This map indicates that the highest geometric mean permeabilities trend in a northeasterly direction in the central part of the study area. The area of highest mean permeabilities also coincides with areas where the sandstones are the cleanest (Fig. 16).

\section{Distribution of Reservoir Properties From Log Interpretations}

The areal distribution of average porosity from the high-permeability barrier island facies (foreshore and upper/middle shoreface) in the study area has been determined by analysis of density log data.

The logs run at Bell Creek have been affected to various degrees by dispersed clays filling the pores. ${ }^{11}$ The density logs seem to be least affected by clay infilling because tests run in the laboratory found the clay density to be between 2.60 and $2.63 \mathrm{~g} / \mathrm{cm}^{3}$, which is near the matrix density of quartz $\left(2.65 \mathrm{~g} / \mathrm{cm}^{3}\right)$. The effect of the dispersed clays on the density logs should, therefore, be small, and the porosities derived from density logs should be reasonably representative of the true or effective reservoir porosity of the barrier sandstone. 


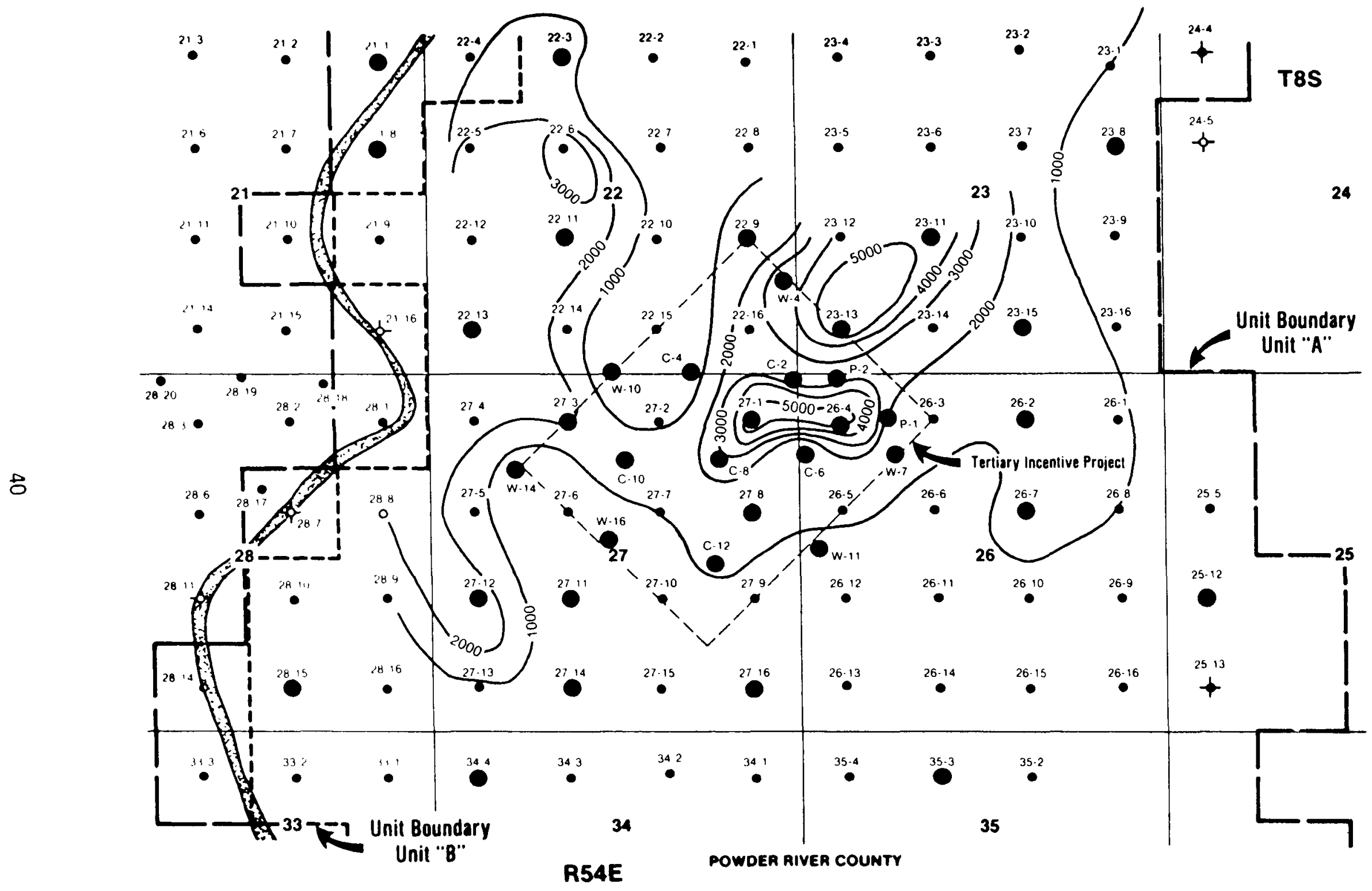

FIGURE 17. - Distribution of geometric means of the air permeability data for wells in the study area. C.I. $=1,000 \mathrm{md}$. Wells with permeability data are indicated by large circles. 
The average porosities of the barrier sandstone obtained from analysis of 51 density logs from the study area have been contoured in Fig. 18. Zones with the highest porosity are located near the axis of the bar and slightly to the east. There are intervening zones with low porosity values between these highly porous zones. Immediately to the west of the axial position are elongated zones with distinctly lower porosity.

The porosity distribution seems to have been affected in certain areas by the structural or diagenetic features previously discussed.

\section{Heterogeneity Index Map}

Analysis of sonic log data from the Bell Creek field indicates that the sonic deflections from the baseline are strongly influenced by inhomogeneities in the sandstones. In a purely homogeneous sandstone, the deflections are nearly uniform through most of the reservoir interval; however, as more and more heterogeneities are introduced, the sonic deflections become much less uniform. $^{12-13}$ The amount of deviation of the sonic deflections from the perfectly homogeneous case is an indication of the type and degree of heterogeneity in the sandstone "framework."

The sonic response $T_{c}$ across a perfectly homogeneous, clean sandstone zone is dependent upon the matrix velocity of the sandstone, the sonic velocity of the pore fluid, porosity, rock compaction, etc. ${ }^{13}$ In the more heterogeneous sandstone, the average deflection, $T_{A V}$, is closely related to the factors influencing the homogeneous sandstone, but the fluctuations in the deflections will be largely determined by the inhomogeneities in the sandstone matrix. An estimate of the amount of fluctuation (which is a function of the degree of heterogeneity) can be obtained by taking the standard deviation of the sonic deflections. The standard deviation (hereafter called the logderivedheterogeneity index (LHI) can be estimated as follows:

$$
L H I=\downarrow \frac{\sum_{i=1}^{N}\left(T_{i}-T_{A V}\right)^{2}}{N}
$$

where $T_{j}$ is the sonic deflection in the ith interval and $N$ is the total number of deflections in the heterogeneous sandstone.

The LHI is a general heterogeneity index and includes all types of Figure 


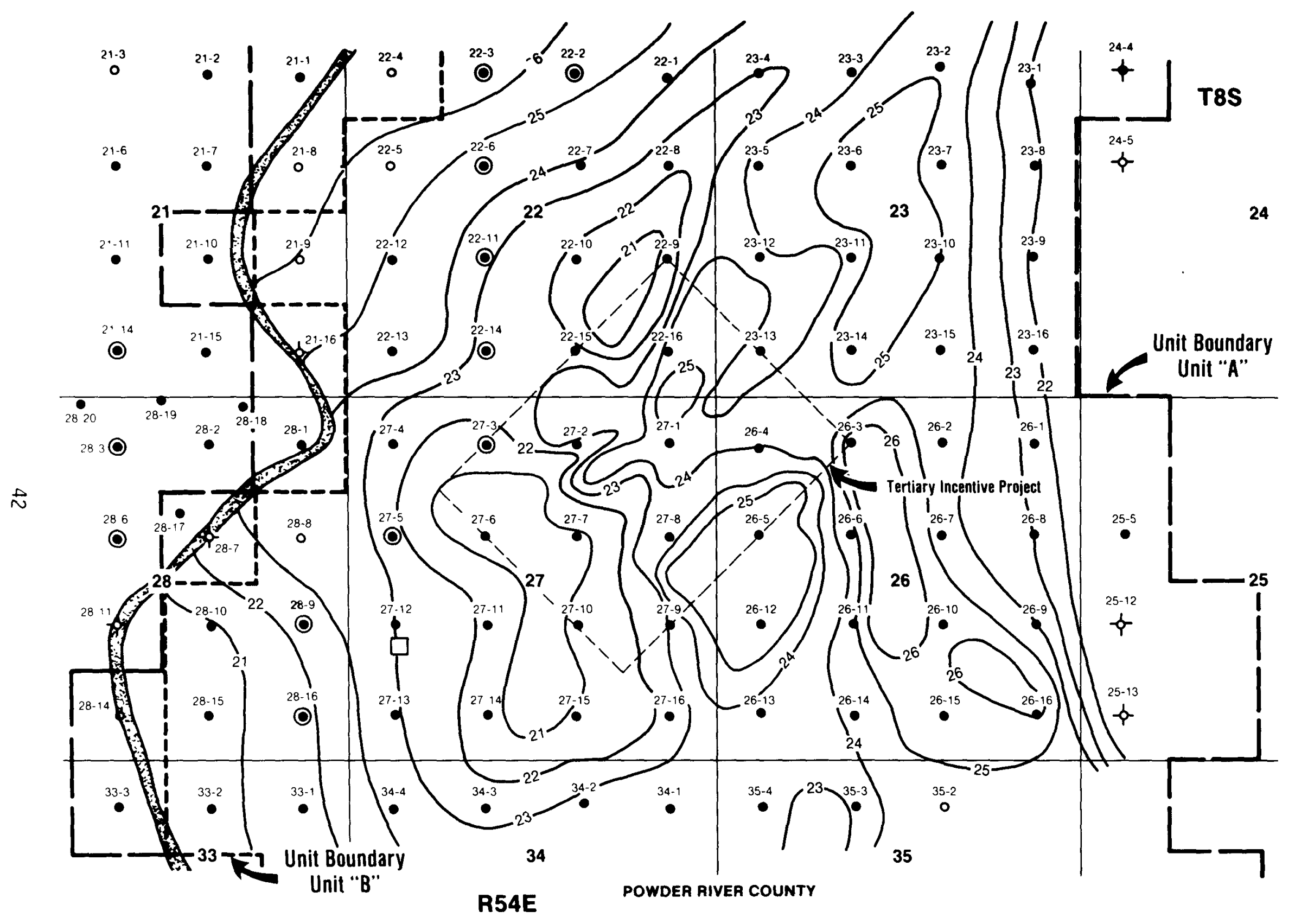

FIGURE 18. - Average log-derived porosities (in percentage) of the barrier island sandstones in the study area. 
inhomogeneities in the sandstone. The magnitude of the LHI values is dependent upon the sonic velocities of these inhomogeneities.

In the study area, 48 sonic logs were analyzed to provide average LHI values of the main barrier island sandstone at the well locations. The distribution of LHI values shown in figure 16 indicates that low LHI values are clustered in the center of the mapped area near the axis of the bar and slightly to the east. Sandstones in this area are relatively "cleaner" and contain very little clay or other cements or their pores are relatively free from compaction. The high LHI values extending north-south through sections 22 and 27 indicate a higher degree of cementation and clay filling. In the extreme northwestern corner of section 22 and extreme southwestern corner of section 27, the LHI values are sma11, indicating good quality of reservoir rocks.

\section{Distribution of Clays}

Combined density and sonic log analyses were performed ${ }^{12-15}$ in order to obtain an estimate of the clay content in the different parts of the bar deposit.

In a friable sandstone, such as the barrier island sandstone at Bell Creek, ${ }^{11}$ the sonic log measures the total porosity of the rock matrix because the dispersed clays respond like slurries to the sonic tool and there is a dampening of transit times in the clay-filled zones.

In a sandstone having dispersed clays, the sonic porosity, $\phi_{S}$, is given by $^{14}$

$$
\phi_{s}=C_{p}\left(\phi+V_{d i s}\right)
$$

where $C_{p}$ is a compaction factor which is greater than 1 , and $\phi$ is the effective porosity, and $V_{d i s}$ is the volume of dispersed clay.

In uncompacted formations, a value for $C_{p}$ may be obtained by comparing $\phi_{S}$ and $\phi_{d}$ (porosity from density logs) in clean, liquid-filled sands. A few clean sandstones from the study area were identified by cross-plotting the density and sonic transit time values for a large number of sandstone samples. Having identified the clean sandstones, the compaction factor, $c_{p}$, is obtained as follows: 


$$
C_{p}=\frac{\phi_{s}}{\phi_{d}}
$$

The average value for $C_{p}$ obtained for the study area is 1.17 .

In equation 2, the density logs provide good estimates of $\phi$ in filtrate invaded and in water sands because the density of dispersed clays (about 2.60 to $2.63 \mathrm{~g} / \mathrm{cm}^{3}$ ), is near the matrix density of the sand which is $2.65 \mathrm{~g} / \mathrm{cm}^{3}$. Therefore, in clean water sands we can assume that $\phi=\phi_{d}$.

The clay volume indicator, $q$ is defined as $V_{\text {dis }} / \phi_{i m}$ where $\phi_{i m}$ is the intermatrix porosity which includes all the space occupied by fluids and dispersed clays. For Bell creek field, a reliable estimate of $\phi_{\text {im }}$ may be obtained from sonic $\log$ data from the relationship $\phi_{i m}=\frac{s}{C_{p}}$.

From equation $2, \frac{\phi_{s}}{C_{p}}=\phi+v_{\text {dis }}=\phi_{d}+v_{\text {dis }}$

and

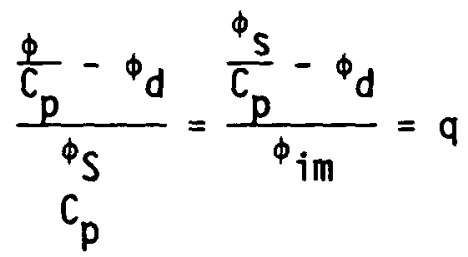

Because permeability in the study area has been strongly influenced by clay content and compaction (see the discussion on Petrography, Porosity and Permeability), the distribution of " $q$ " values is expected to correlate with fluid recovery trends in the study area. The distribution of "q" values plotted as a percentage of intermatrix porosity is shown in figure 15 . The map indicates elongated, relatively clay-free zones in the central and eastern part of the mapped area, with intervening zones of high clay content. The clay content increases to the west and southwest in the central part of section 27 and directly north of it. The distribution of clay content has strongly affected fluid production in the study area as discussed further under Production Performance Analysis.

\section{PRODUCTION PERFORMANCE ANALYSIS}

\section{Primary Production Analys is}

In most cases, production from the Muddy sandstone has been both from the upper sandstone (assumed to be nonbarrier) and from the barrier island sandstone. Compared to the barrier island sandstone, the upper sandstone is 
much thinner. Its overall permeability and porosity are normally much less; therefore, its contribution to overall production is also proportionately much less in most places.

A map of primary reserves covering 4 square miles $\left(10.36 \mathrm{~km}^{2}\right)$ in sections $22,23,26$, and 27 was prepared from production decline analyses of all the producing wells extrapolated to $1 \mathrm{STB} / \mathrm{d}\left(0.15 \mathrm{~m}^{3} / \mathrm{d}\right)$ per well (Fig. 19). This isoprimary reserves map shows that regions of highest primary reserves are two elongated zones running north-south in the central part of the area of investigation.

Based on the cumulative primary production map (September 1970) and primary reserves (Figs. 19 and 20) in the study area, it is determined that the primary production was interrupted by initiation of waterflooding when two-thirds of the primary reserves had been produced. Comparison of figures 19 and 20 indicates that wells with high cumulative primary production generally appear where the primary reserves are high.

However in a few places, the primary production did not always deplete the regions with high primary reserves at a rate proportional to the reserves (Figs. 19 and 20). Examples of such production anomalies are in the western half of section 23, in the well 26-3 area, the northeastern quarter of section 27, and the region around wells 27-9 and 27-10. It is also evident from these maps that wells near the eastern extremity of Unit A have lower reserves because both net pay and porosity decrease toward the lagoonal (eastern) part of the barrier island reservoir.

Low primary reserves and production also occur in the region around wells 26-6 and 26-11. In addition, figure 19 indicates a wide variation in reserves along the western edges of sections 22 and 27 . These variations are partly due to reservoir heterogeneities and partly due to the variable position of the oil-water contact.

It is expected that the peak monthly primary oil production rate in the study area shown in figure 21 is influenced by nongeological factors. These include paraffin deposition, sand production, stimulation practices, and completion practices as well as state regulations. The peak monthly oil production rate occurred between the latter parts of 1967 and 1968. The region of the highest peak primary production rate is in the southeastern 


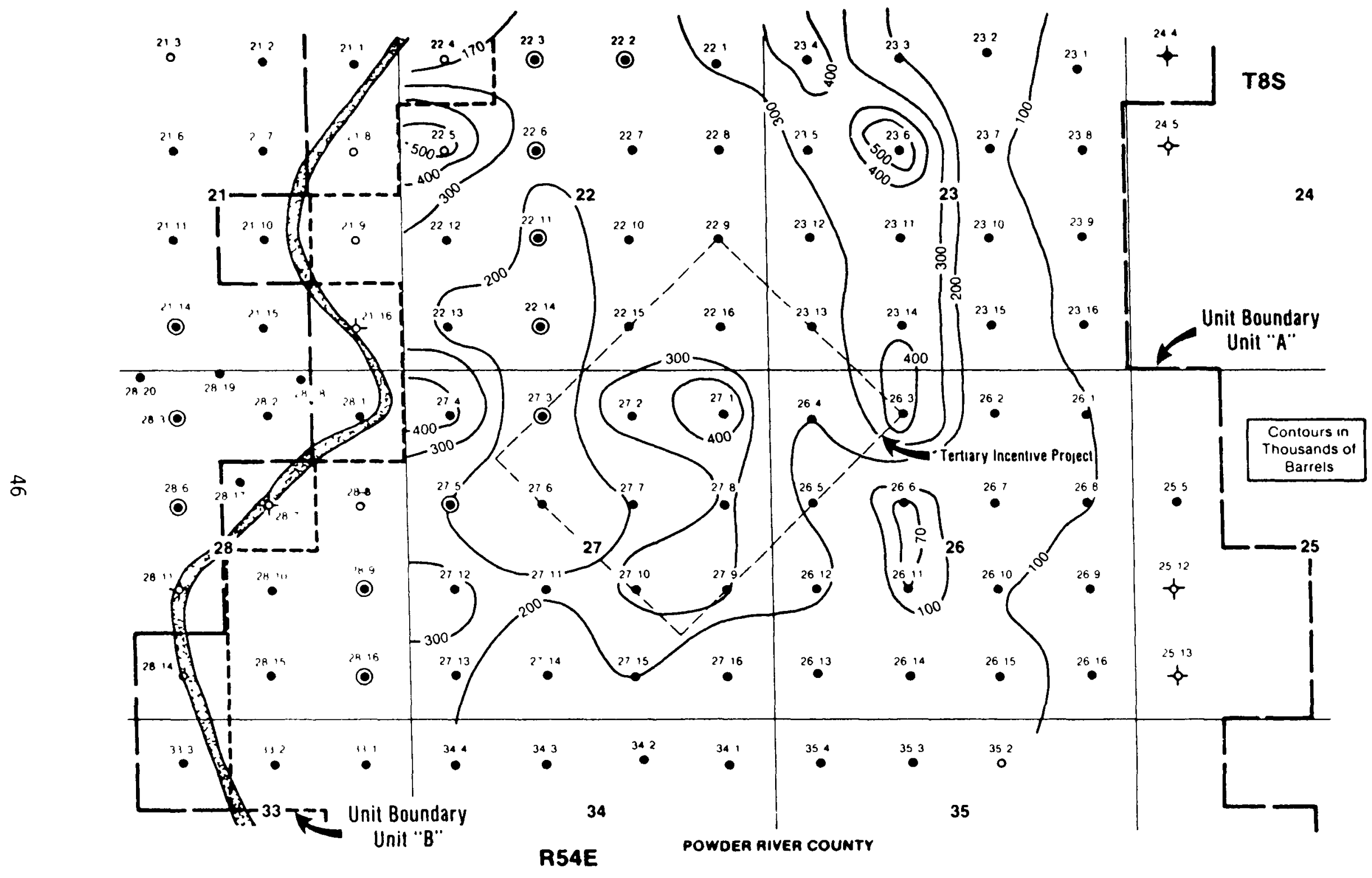

FIGURE 19. - Distribution of primary reserves in thousands of barrels in the study area based on production decline analysis. 


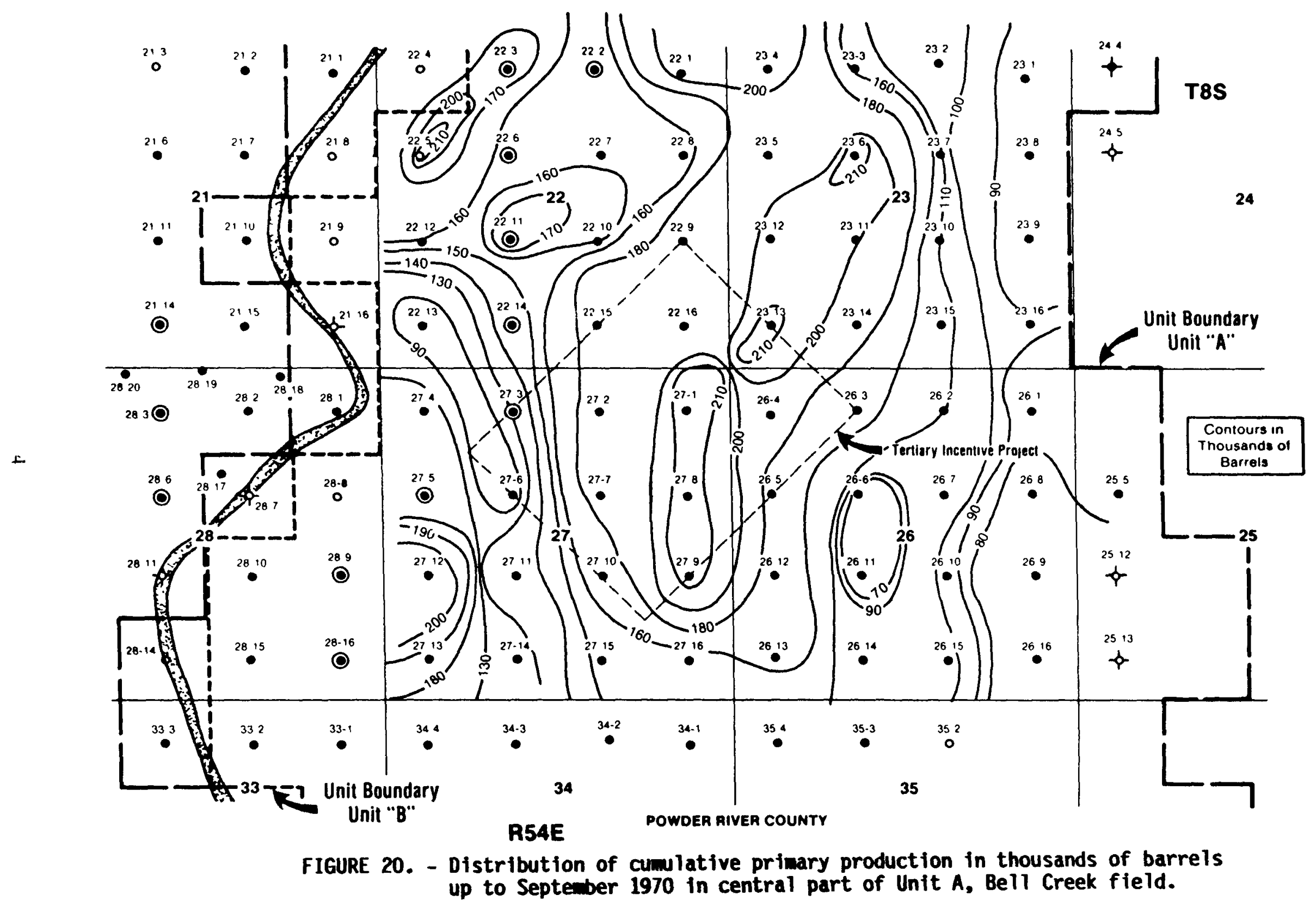




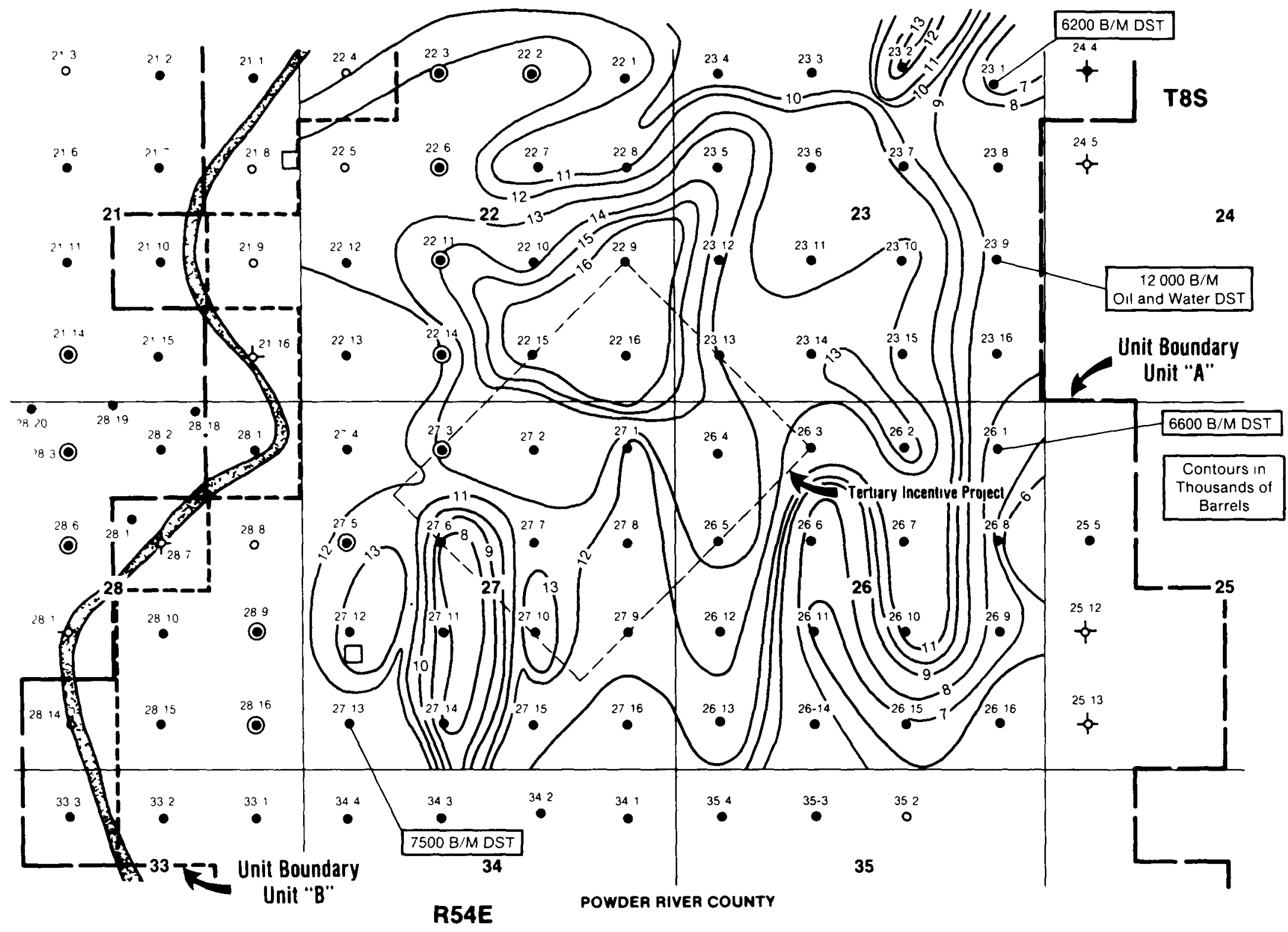

FIGURE 21. - Monthly peak primary oil production rate in thousands of barrels/month in the central part of Unit A, Bell Creek field. 
quarter of section 22 . Rather sharp drops in the peak oil production rate occurred along the eastern and southern boundaries of section 22, indicating that lower transwissibilities exist in this region. This is also evident from the analysis of pulse tests performed in this region (Fig. 22). Results of a limited number of drillstem tests performed im the four sections under stumdy agree with the pattern of peak primary production in the boundaries of sections 23, 26, and 27. Comparison of regions of high peak production rattes with regions of high cumulative primary production (Fig. 20) and reserves (Fig. 19) shows that the three regions do not allways coincide. Regions of high cumulative primary production and high primary reserves coincidde witth regions of highest geometric wean permeabillity, Movest heterogeneity indices, low clay content, and low Dykstra-Parsons coefficients (Figs. 14, 16-21). This might be due to fracturing occurring in association with faulting of the producing sandstone, or the presence of the high-penmeability layer in this region.

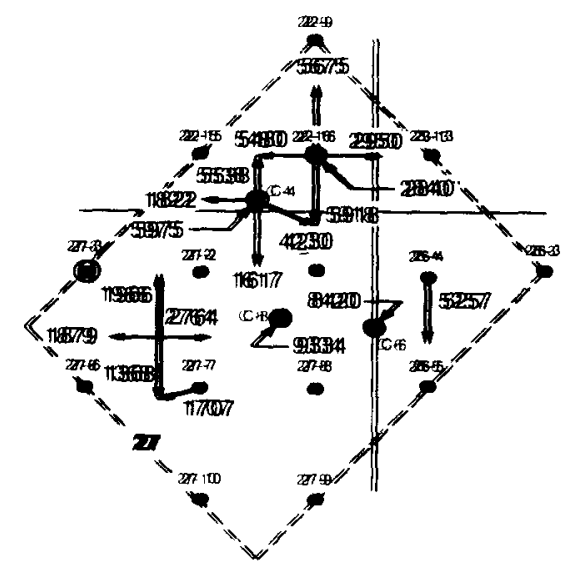

FIGURE 22. - Pressure pullse and fallloff test results prior to initiation of chemical flooding. The large numers beside an arrow indicate water flow capacity in the indicated direction. 


\section{Secondary Production Analys is}

A map showing cumulative waterflood production through September 1986 has been prepared for watercuts exceeding the 90 percent level for most parts of the study area (Fig. 23). Initially, injection wells were located in the western part of sections 22 and 27 , and additional injectors were later completed in the eastern part of Unit A. In 1978, a line of injectors was located in section 23 that extended northward into section 14. Later most of the injection wells were recompleted to improve the flooding of the barrier island sandstone. Waterflooding of Unit $A$ succeeded in recovering more than 50 percent of the OIP, greatly exceeding what would have resulted from primary production. Examination of the isocumulative waterflood production map (Fig. 23) shows that in spite of the presence of heterogeneities in the study area, the linedrive pattern of flooding resulted in good recovery in some parts of the barrier including the middle of section 23 and the northern half of section 26. The injected water pushed the oil updip into the thinner part of the barrier and still further updip within the lagoon where the reservoir properties deteriorated rather abruptly and the sandstones have low permeabilities.

However, the presence of heterogeneities around we11s 26-6, 26-11 and extending toward wells 26-10 and 26-9 interrupted the high waterflood recovery trend in the middle of section 26 (Fig. 23). Figure 23 also shows an anomalous zone separating sections 22 and 23 .

\section{Secondary Waterfront Movement Analysis}

The injection information for Unit $A$ of Bell Creek field was analyzed and mapped (Fig. 24). The advance of the 20 percent water production front through January 1981 indicates that two north-south and east-west oriented discontinuities have contributed to the lack of transmissibility across the field (near the junction of sections 22, 23, and 27) during the waterinjection process. The advancing waterfront in the reservoir also was influenced by the presence of clay-filled zones. As an example, heterogeneities around wells 26-6, 26-11, and 26-10 have adversely affected waterfront advancement.

Heterogeneities around wells $23-15,23-16$, and $26-2$ have also retarded 


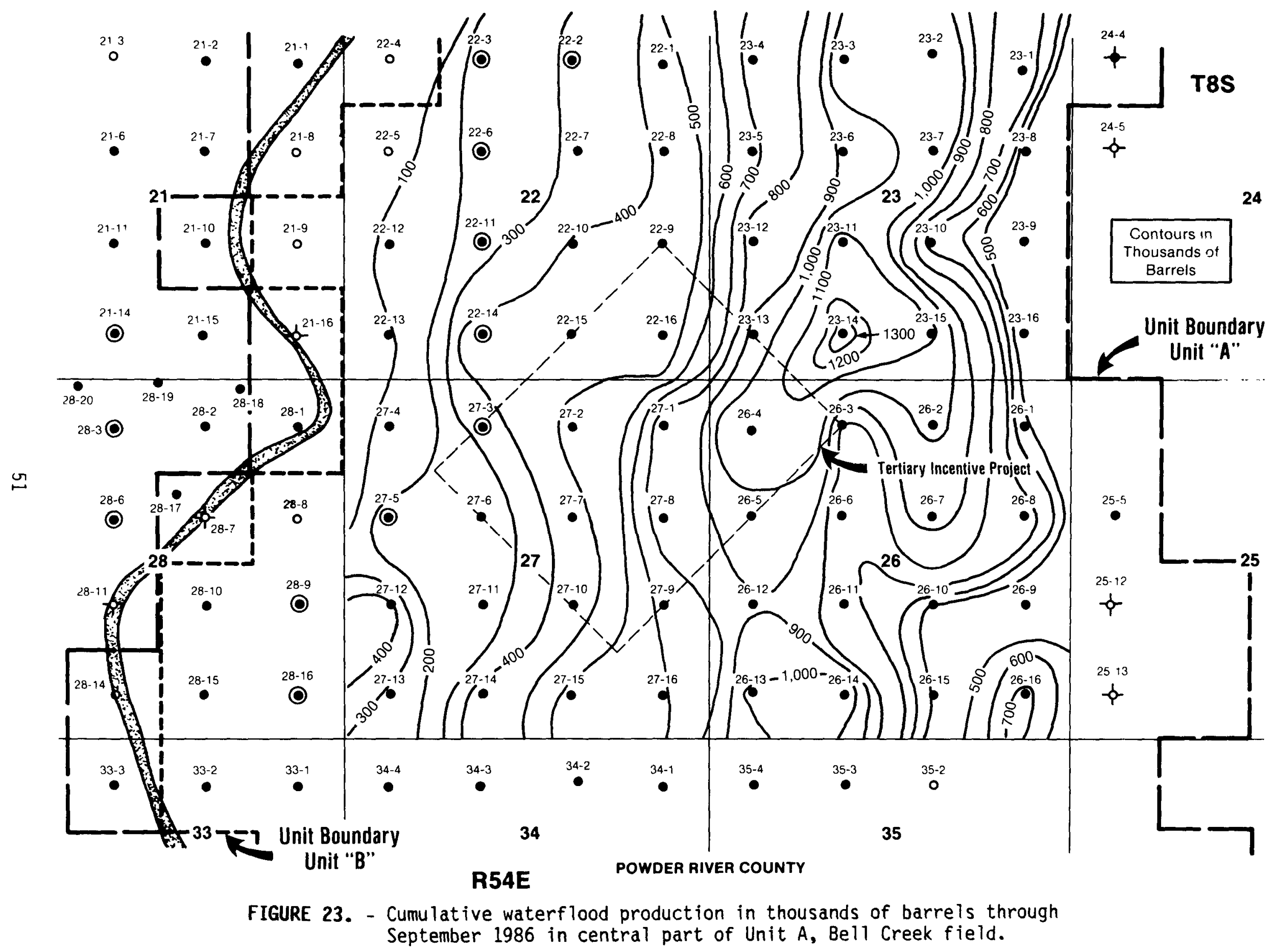




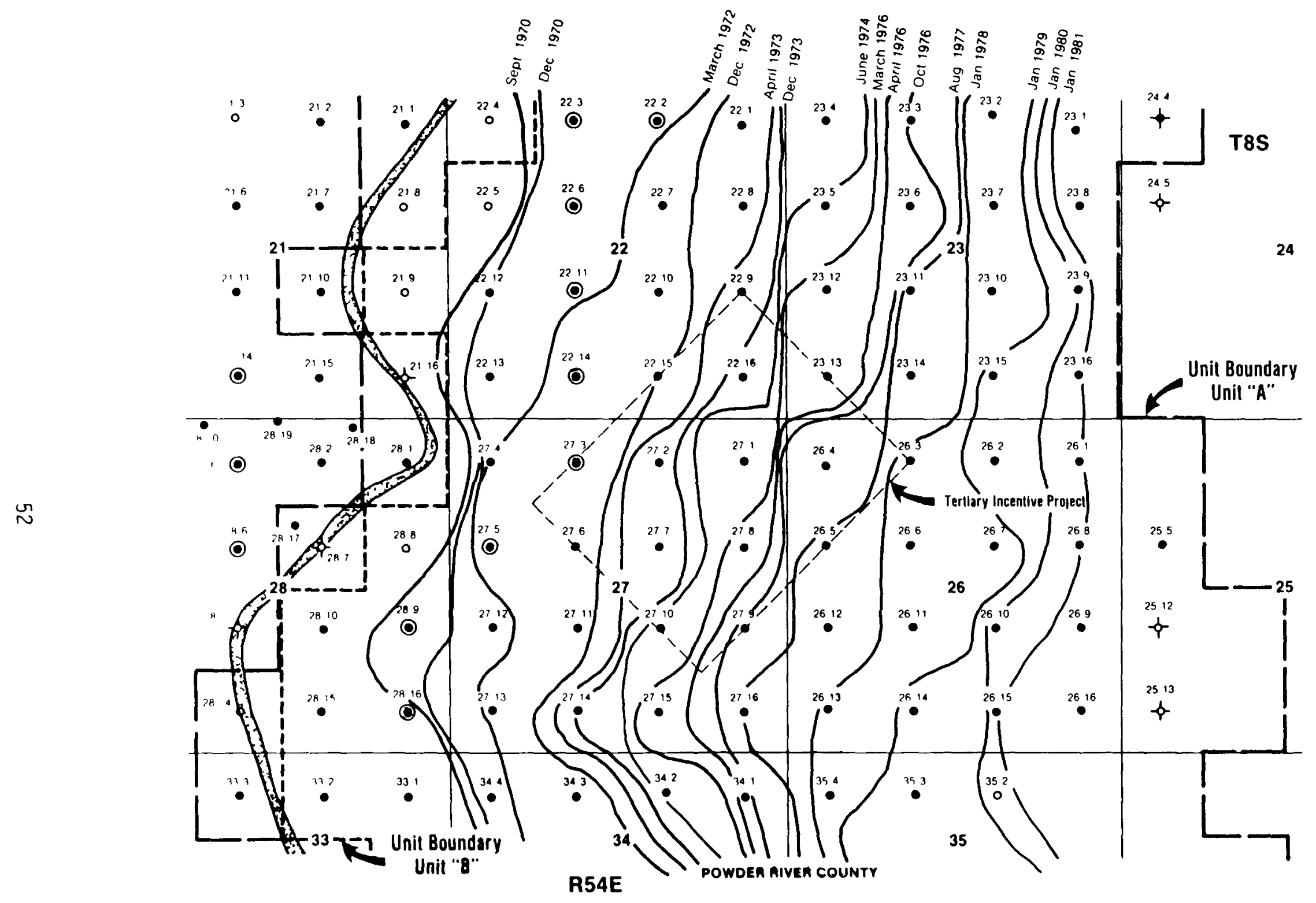

FIGURE 24. - Twenty percent water advancement map through January, 1981. 
normal fluid movements. Normal water advancement occurred in regions with best reservoir properties as indicated in clay, reserve, and production maps. Early water breakthrough was recorded in wells 22-9 and 22-10; this is attributed to high-permeability channeling, the exact nature of which is presently under investigation.

\section{Tertiary Production Analysis}

A tertiary cumulative production map (production from December 1980 to May 1986) of the TIP area is shown in figure 25. Chemical flooding during the tertiary phase of production was conducted with 10 -acre $\left(40.47 \times 10^{3} \mathrm{~m}^{2}\right)$ we 11 spacing, ${ }^{16}$ and a series of water injectors was placed around the pilot to prevent the escape of the injected chemical and mobilized crude oil. Examination of the cumulative tertiary production map shows that the highest oil production occurs mainly where the clay content of the formation was least and the primary production was highest (Figs. 15 and 20).

\section{Pressure Transient Testing Analysis}

Several pressure-pulse tests and falloff tests were conducted in the TIP area in the later stages of waterflooding (Fig. 22). The pulse test results show the variation of flow capacity (Kwh). Indications are that the flow capacity is reduced at the boundaries between sections 22 and 27 and between sections 22 and 23 and in the middle portion of section 27 . These tests indicate good flow capacity around wells 26-4, C-6 and C-8.

\section{VERIFICATION OF GEOLOGICAL AND ENGINEERING MODEL OF RESERVOIR}

Figure 26 summarizes the primary reserves distribution and primary, secondary, and tertiary production performances in the study area of Bell Creek field. By comparing production data from each of these stages with areas of known and probable geologic heterogeneities, an assessment may be made of the accuracy of the geological and engineering model of the reservoir developed. In the production performance analysis, production from both the upper (valley fill) sandstone and the barrier island sandstone have been considered, whereas present analysis of geological heterogeneities from logs has been for the barrier island sandstone only. Since there will be at least some contribution to production from the upper sandstone in most places, exact 


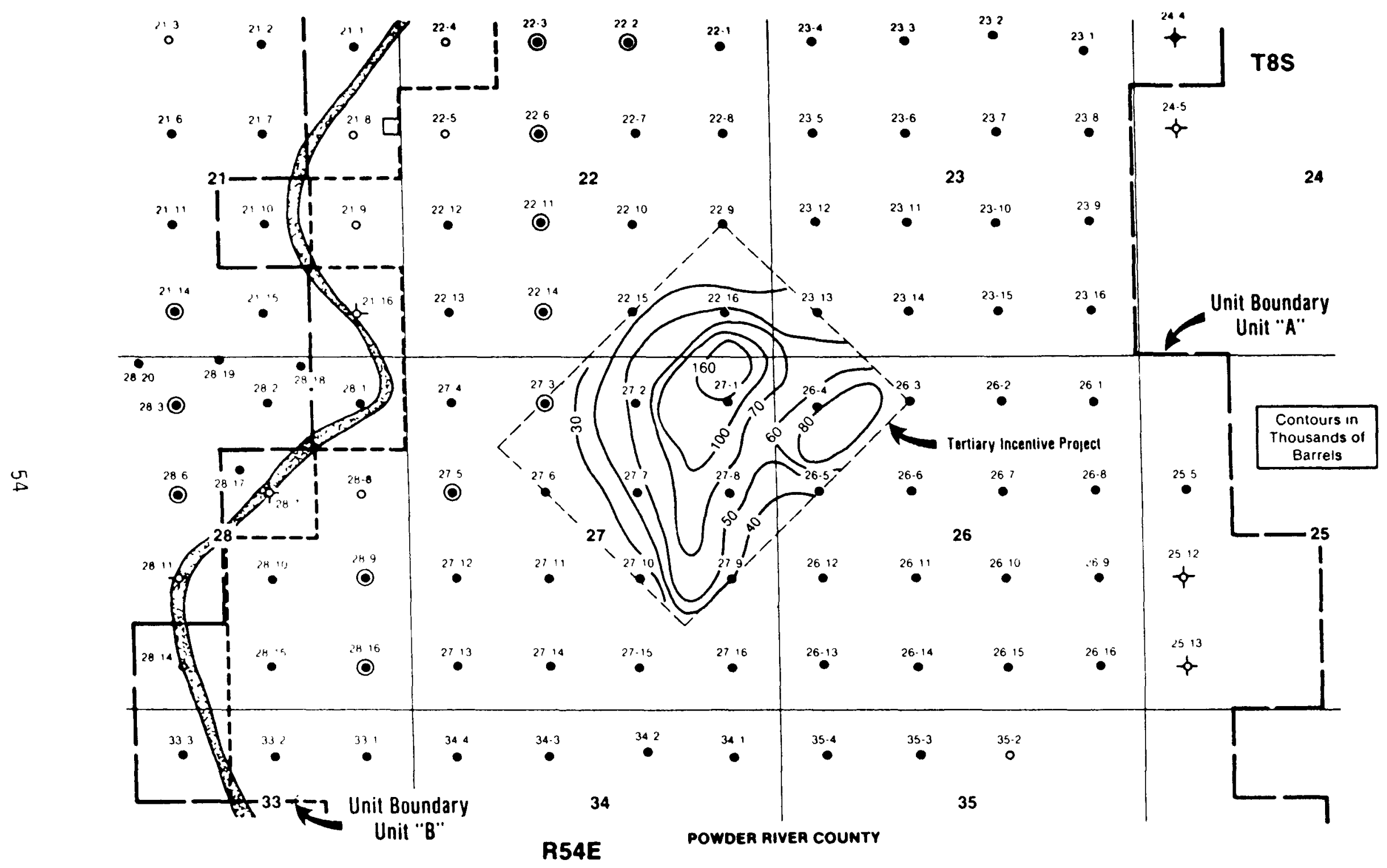

FIGURE 25. - Tertiary cumulative production in thousands of barrels in the TIP area as of May 1986. For detailed locations of wells in the TIP area refer to figure 1 . 


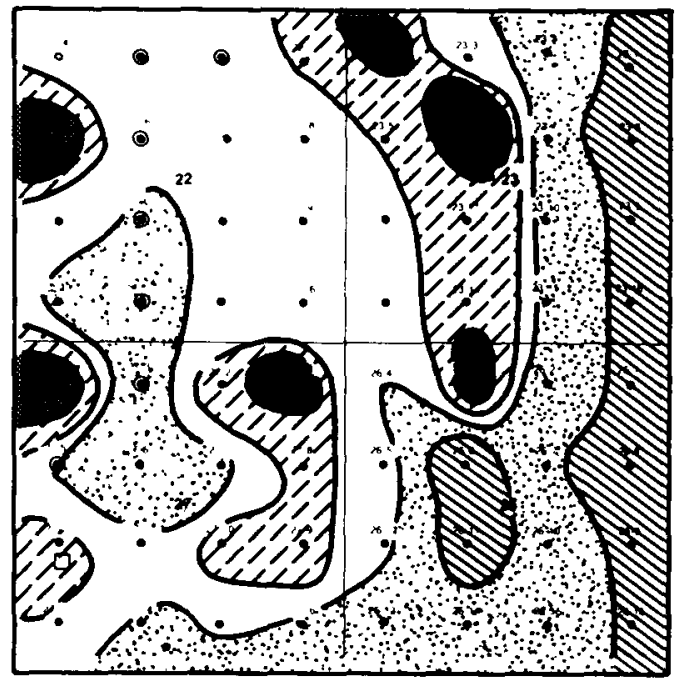

Primary Reserve

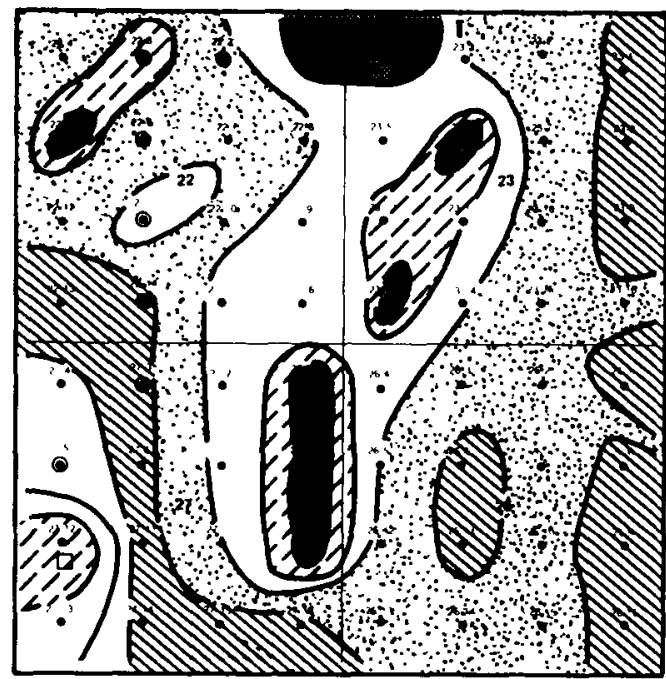

Primary Cumulative Production

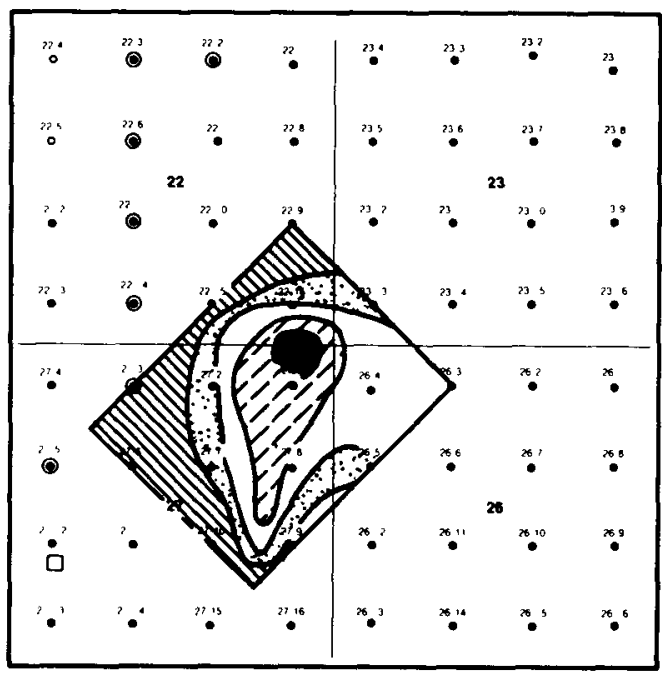

Tertiary Cumulative Production

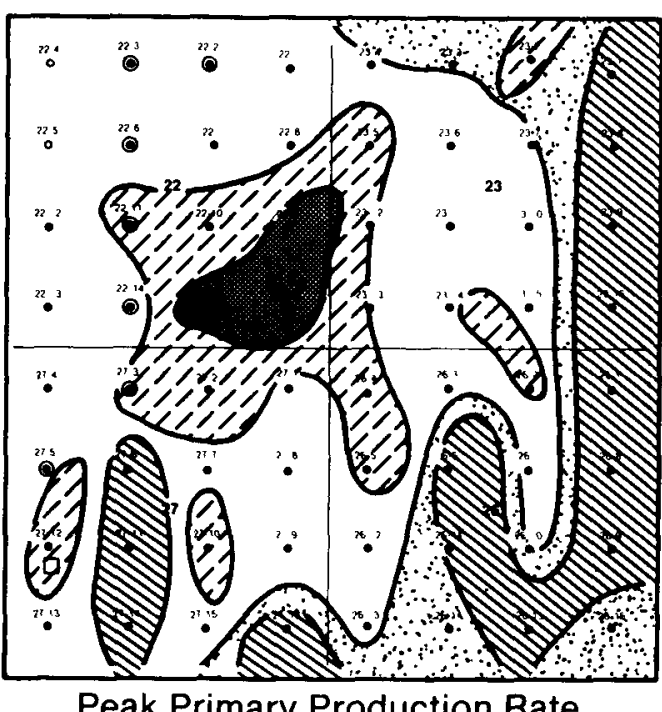

Peak Primary Production Rate

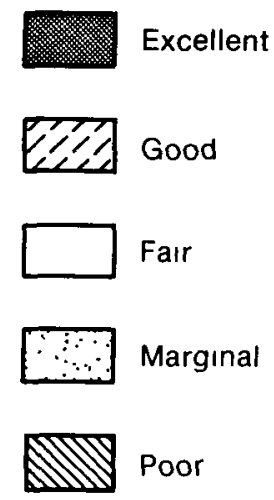

Secondary Cumulative Production

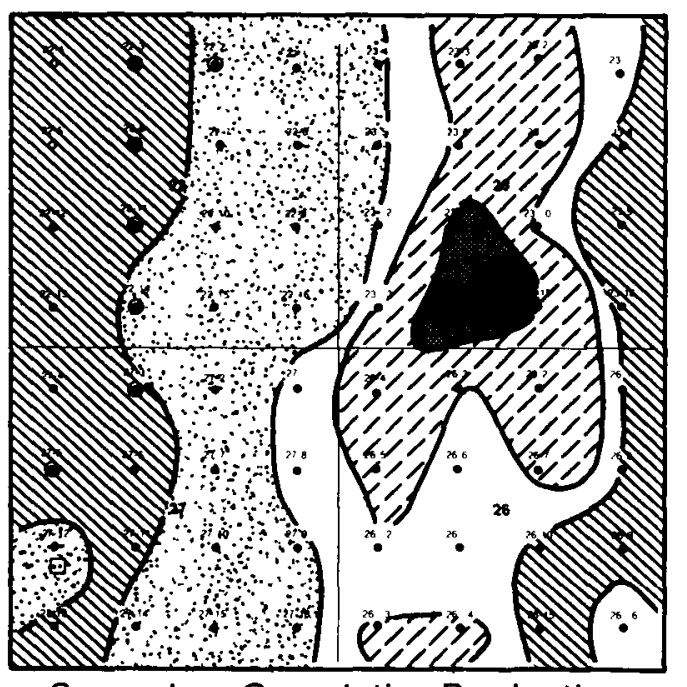

FIGURE 26. production results in the study area of Unit $A$ in Bell Creek field. 
correspondence is not expected between production data and geological heterogeneities. Major geological and production anomalies were observed in the following areas:

1. Increased heterogeneity resulting from clay cementation or compaction around wells 22-13 and 22-14 (Figs. 15 and 16) has adversely affected the productivity and reserves in this region even though the thickness of the barrier sandstone in section 22 is near maximum. The index of heterogeneity in the nearby well 22-11 is also high (Fig. 16), but there is a thin high-permeability layer in this well which is probably responsible for the good ultimate primary recovery and peak primary production rates (Figs. 20 and 21) from this well. From the deflection of the peak production rate contours (Fig. 21), it appears that the high-permeability layer trends in a northwesterly direction in this area.

2. Lower primary reserves in wells 22-9 and 22-16, rapid depletion of these wells, and poor communication between wells 22-16 and P-3 (Figs. 19-24) indicate the possibility of the presence of some structural or diagenetic features close to the boundary between sections 22 and 23. This anomaly may be responsible for lower transmissibility that restricts the drainage volume of these wells as well as the restriction of injection water movement across the field.

3. Lower flow capacity as indicated from pulse tests and rapid lateral variations in reserves, peak production rate, and cumulative primary, secondary, and even tertiary production data (Figs. 20-25) indicate the possible presence of flow barrier in the southeastern corner of section 22. Abrupt changes in contour orientation on the structural contour map (Fig. 10) suggest the possible presence of a northwestsoutheast striking fault in this region or valley incisions into the best productive sandstones. The high peak primary $0 i 1$ production rate in the region around wells 22-7,22-15, and 22-16 and very early water breakthrough in well 22-9 might also be explained by the presence of high-permeability channels.

4. Lower storage and flow capacities are observed along the eastern boundaries of sections 23 and 26 due to interfingering of backbarrier and lagoonal facies. The low permeability of the backbarrier facies 
has acted as a barrier for the oil bank during waterflood recovery. Therefore an elongated zone running north-south in the middle of sections 23 or 26 shows the best waterflood performance. The reservoir characteristics in this area are also good, with the sandstones having good porosity, permeability, and moderate clay content (Figs. 15, 17, and 18).

5. Relatively low values of peak production rate, primary reserves, and cumulative primary and secondary production are observed around wells 26-6 and 26-11. The higher percentage of clays (Figs. 15 and 16), which may be either diagenetic or detrital, may be related to a later valley incision into the barrier island and may also be responsible for the poor production performance in this area. Presence of this heterogeneity and the location of water injectors with respect to this anomaly have influenced the secondary recovery performance of the entire southeast portion of section 26 (Fig. 23).

6. The continuation of the heterogeneity discussed in item 1 appears around we11s 27-6 and 27-11, in section 27, influencing the peak production and reserves distribution in this area. The presence of diagenetic clays indicated by petrographic observations (Fig. 13) or structural features may be the cause of drastic reduction in porosity and permeability in this region. The barrier island thickness, however, is near maximum in this area. Note that the postulated structural or diagenetic features pass in a north-south direction through the anomalies mapped in the center of section 27 (Figs. 15 and 16). The secondary production performance of the surrounding wells (such as wells 27-14 and 27-15) was significantly improved due to the diversion of injected water around the low-permeability zone or the recompletion of the injectors in the upper sand, or both.

7. Reservoir quality is quite variable along the western margin of sections 22 and 27 . This is reflected in the porosity distribution (Fig. 18), heterogeneity index (Fig. 16), clay content (Fig. 15), Dykstra-Parsons coefficient (Fig. 14), primary peak production rate, and reserves maps (Figs. 19 and 21). This alteration in production behavior cannot be readily explained by inferred barrier island architecture; however, it may be related to the proximity to valley fill or water-oil contacts that define the western margin of Unit A. 
The high cumulative oil production in some of these areas is attributed to the presence of the high-permeability layers discussed in item 1.

8. The western margin of Unit $A$ is terminated by a valley cut and fill resulting in an abrupt change in reservoir quality from good to nonreservoir facies (Fig. 5).

9. Regions of highest cumulative primary or waterflood production have highest geometric mean permeability (Fig. 17) but do not coincide with regions of highest peak production rates (Fig. 26). Highest peak oil production rate appears to be influenced by state production regulation guidelines.

10. The best part of the reservoir with high storage and flow capacities, as indicated by highest primary cumulative production, reserves, and highest geometric mean permeability (Figs. 17, 19-20), are in the northeastern portion of section 27 and the southwestern portion of section 23. The sandstones in this area have the best reservoir quality; they have the least clay content and are the thickest (Figs. 11, 15, and 16). Slightly west of the above area is the part of the barrier with highest peak primary production rates (Fig. 21).

11. The region with highest tertiary production agrees well with the region having lowest clay content (Figs. 15 and 16), highest primary reserves (Fig. 19), and highest cumulative primary production rate (Fig. 21). This observation clearly demonstrates the high sensitivity of chemical EOR production to clay content in sandstone formations.

\section{CONCLUSIONS}

1. A geological model has been constructed providing significantly improved sedimentologic and stratigraphic evaluation of the barrier island Muddy reservoir and related deposits that contained detailed information for identification of major heterogeneities on a variety of scales.

2. A wide variety of scales of heterogeneities occur within the field. Large-scale heterogeneities are the result of facies changes, valley fills, sand-shale boundaries, and faults; moderate scale heterogeneities result from clayey beds, cemented zones (clay and calcite), and high permeability channels (perhaps fractures); small- 
scale heterogeneities are due to diagenetic clays, compaction effects, leaching of minerals, and cementation.

3. Production in Unit $A$ is primarily from several stacked shallowing-up barrier-island sandstones. Within the barrier, facies recognized are foreshore, upper shoreface, lower shoreface, transition, washover and perhaps a backshore. Two periods of postbarrier erosion and shale and sandstone valleyfill are related to two fluctuations in sea level. Earlier valley incisions were broad and relatively shallow and commonly involved reworking the top of the barrier. Younger valley fill deposits along the west side of Unit $A$ are $30 \mathrm{ft}$ thick where erosion has cut completely through the barrier.

4. Production/injection performance analysis in the 4 section area of the barrier island field at Be11 Creek indicates good correlation between the improved geological model of the reservoir and the associated heterogeneities with fluid production and injection patterns in the primary, waterflood, and tertiary methods of $0 i 1$ recovery.

5. The investigation demonstrated a strong influence of multigenetic (depositional, diagenetic, and structural) heterogeneities on fluid movement in the reservoir.

6. The highest quality reservoir sandstone (with good porosity, permeability, and low clay content) is encountered in the central part of the barrier island deposit. In the distal parts of the lagoonal side of the barrier where thinner and lower energy facies intercolate with nonproductive facies, the reservoir quality is poorer. NE-SW trending zones with good production performance (high porosity and permeability) are generally oriented parallel to the depositional strike of the barrier island sandstones. Cement-rich, poor-quality reservoir sandstones occupy areas between the highly productive zones.

7. The area showing the best waterflood performance lies between the central part of the barrier deposit and the backbarrier facies. This is attributed to low-permeability facies acting as a barrier to the oil bank swept by the water during waterflood recovery. 


\section{REFERENCES}

1. Moody, J. A., J. W. Mooney, and J. Spivak. Giant Oil Fields of North America. Geology of Giant Petroleum Fields, M.T. Halbouty (ed.) AAPG, Memoir 14, 1970.

2. Davies, D. K., F. G. Ethridge and R. R. Berg. Recognition of Barrier Environments. AAPG Bu17., v. 55, No. 4, 1971 pp. 550-565.

3. Szpakiewicz, M., K. McGee, and B. Sharma. Geological Problems Related to Characterization of Clastic Reservoirs for Enhanced 011 Recovery. Pres. at the 1986 SPE/DOE Symposium on Enhanced 011 Recovery Tulsa, Apr. 20-23. SPE/DOE paper 14888.

4. Szpakiewicz, M., S. Jackson, and R. Tillman. Sedimentologic Description of Barrier Island and Related Deposits in the Bell Creek Cores, Montana and Ana logous Outcrops Near New Haven, Wyoming. NIPER Open File, 1986-87.

5. McGregor, A. A. and C. A. Biggs. Bell Creek Field, Montana: A Rich Stratigraphic Trap. AAPG Bu11., v. 52, No. 10, 1968 pp. 1869-1887.

6. Stone, W. D. Stratigraphy and Exploration of the Lower Cretaceous Muddy Formation Northern Powder River Basin, Wyoming and Montana. The Mountain Geologist, v. 9, No. 4, 1972 pp. 355-378.

7. Almon, W. R. and D. K. Davies. Regional Diagenetic Trends in the Lower Cretaceous Muddy Sandstone, Powder River Basin. SEPM Special Publication No. 26, Mar. 1979, p. 379-400.

8. Weimer, R. J. New Age Interpretation of Bell Creek Sandstone, Powder River Basin, Montana and Wyoming. AAPG Bul1., v. 69, No. 5, 1981, p. 870.

9. Forgotson, J. M. Jr. and P. H. Stark. Well Data Files and The Computer, A Case History from Northern Rocky Mountains. AAPG Bull., v. 56, No. 6, 1981, pp. 1114-1217.

10. Craig, F. F., Jr. The Reservoir Engineering Aspects of Waterflooding. SPE AIME, Monograph Series.

11. Gary Williams 011 Producers Inc. Engineering and Geological Report, Bell Creek Field, Unit A, 1969. Available from NIPER, Bartlesville, OK.

12. Geertsma, J. and D. E. Smit. Some Aspects of Elastic Wave Propagation in Fluid Saturated Porous Solids. Geophysics, v. 26, No. 2, 1961, pp. 169182.

13. Wyllie, M. R. J., A. R. Gregory, and L. W. Gardner. An Experimental Investigation of Factors Affecting Elastic Wave Velocities in Porous Media. Geophysics, v. 23, No. 3, 1958, p. 459-493.

14. Schlumberger Limited. Log Interpretation, v. I. Principles, 1972. 
15. Open-hole Logging. Reprint Series, SPE, Richardson, TX, 1986, 21.

16. Gary Williams 0il Producers Inc. A Reservoir Engineering Study To Determine Feasibility of Tertiary Recovery Operations. Prepared by C. R. Smith and Associates, June 15, 1974. 